\title{
航空機用アルミニウム合金開発の最近の動向
}
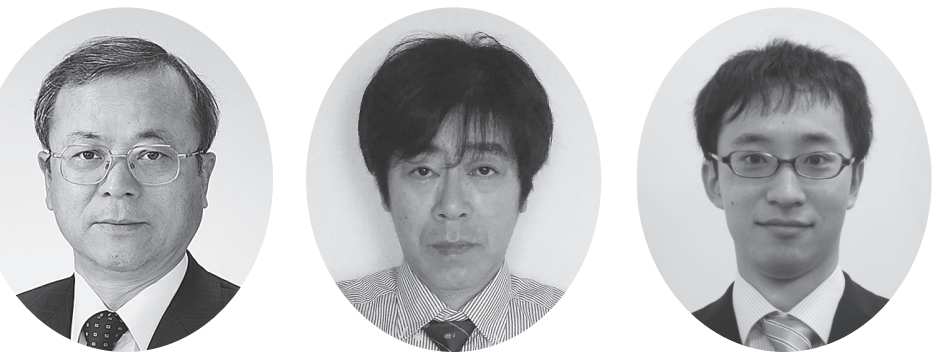

吉田 英雄 $*$. 林 稔* · 則包 一成 $*$

Journal of The Japan Institute of Light Metals, Vol. 65, No. 9 (2015), 441-454

(c) 2015 The Japan Institute of Light Metals

\section{Recent trend of development in aluminum alloys for aircraft}

\author{
Hideo YOSHIDA*, Minoru HAYASHI* and Kazushige NORIKANE*
}

Keywords: aluminum alloy, aircraft, MRJ, 787, 380, Al-Li alloy

\section{1.はじめに}

日本の航空機用アルミニウム合金の開発の歴史について, 戦前の零式艦上戦闘機からボーイング 777 にいたるまでの航 空機との関連で別報にて述べた ${ }^{1)}$ 。そこで見えてきたもの は, 戦前の日本は「航空機大国」であり，国策として，アル ミニウム産業がほとんど航空機材を生産していたこと，その ための設備投資が大規模に行われたことなどであった。戦後 のアルミニウム産業はこれらの設備を基盤に民需に転換し て，飛躍的な発展をとげた。一方の日本の航空機産業もま た，戦後の航空機禁止令から航空機の製造が解禁されるまで の「空白の7年間」を乗り越えて, 米国のボーイング社の機 体生産の分担をすることで復活してきた。しかしながら，あ くまでもボーイング社の枠内での生産のため, 国内のアルミ ニウム産業はボーイング社の材料認定取得のみで, 新材料開 発には至らないのが現状である。米国の開発した合金の追試 や米国での材料製造の難しいところをカバーする形で研究開 発が進んできたのが実情であろう。日本での航空機用材料の 市場が小さいので，日本の航空機材料の研究開発に対する投 資は，米国と比べても比較にもならないほど少ない。航空機 材料の現実に起きている問題点はボーイング社に行かないと わからないと言われているが，この点でアルコア社はボーイ ング社と密接な関係で材料開発してきている。

現在, 幸いなことに三菱重工業と三菱航空機が設計, 生産 を行い，国産の小型ジェット旅客機MRJが飛び立つところ まできている。我々素材メーカーもこれをビジネスチャンス と捉え，これを契機に現状の航空機用アルミニウム合金の問 題点を把握し，新しい国産のアルミニウム合金が機体メー
カーとともに開発できれば, 日本での航空機材料の研究開発 も発展していくものと確信している。21世紀になって新し い航空機が開発され，それに伴い新合金が適用されるように なってきている。ここでは最近の航空機用アルミニウム合金 開発の動向について整理し，我々の進むべき道を述べたい。

\section{2. 最近の航空機とアルミニウム材料の動向}

\section{1 ボーイング777までの航空機とアルミニウム合金開発}

表 1 は航空機用アルミニウム合金の開発の歴史とそれが最 初に適用された航空機の関係である ${ }^{2)}$ 。合金成分, 調質等に よる強度, 勒性, 疲労強度, 応力腐食割れ性の改善が反映 されていることがわかる。特に高強度高勒性が非常に重要 なキーワードで, 図1は高強度でかつ高勒性材料の開発が依 然として求められていることがわかる2)。図2はボーイング 777 に使用されている合金である31。

表 1 航空機とそれに用いられた新合金 ${ }^{2)}$

\begin{tabular}{c|l|l}
\hline \hline 年 & \multicolumn{1}{|c}{ 機種 } & \multicolumn{1}{|c}{ 合金, 調質 } \\
\hline 1903 & Wright Brothers & Al-Cu casting \\
1919 & Junkers F13 & $2017-T 4$ \\
1935 & DC-3 & $2024-T 3$ \\
1954 & B-707 & $7075-T 651,7178-T 651$ \\
1979 & B-767 & $2324-T 39,7150-T 651$ \\
1994 & B-777 & 7055-T7751, 2524-T3 \\
2004 & B-777 ER & 2324-T39 Type II (2624-T39) \\
\hline
\end{tabular}

*株式会社UACJ 技術開発研究所（－４55-8670 愛知県名古屋市港区千年3-1-12） Research \& Development Division, UACJ Corporation (3-112 Chitose, Minato-ku, Nagoya-shi, Aichi 455-8670) E-mail: yoshida-hideo@uacj.co.jp 受付日：平成27年6月28日受理日：平成27年7月 16 日 


\section{2 ボーイング 787}

1995 年に就航開始した 777 に次ぐ機種の開発を検討してい たボーイング社は，将来必要な旅客機は音速に近い速度で巡 航できる高速機であると考え，2001年初めに 250 席前後のソ ニック・クルーザーを提案した。しかし運航経費を抑えたい という航空会社各社の関心を得ることができず，2002年末 にこのソニック・クルーザー開発を断念して通常型 7E7 の開 発に着手した。この通常型7E7は, 速度よりも効率を重視し たボーイング 767 クラスの双発中型旅客機である。2004年 4 月に全日空が50機発注したことによって開発がスタートし, 呼称も 787 に改められた。2011年9月28日, 初号機となった 全日空向けの第 1 号機が東京国際空港に到着した ${ }^{4), 5) 。 ~}$

ボーイング社は787の開発では同じクラスの従来機より効 率（主として燃費）を $20 \%$ 向上させることを最大の主眼とし ていた。20\%向上させるために, エンジンが $8 \%$, 空力, 素 材，新システムがそれぞれ $4 \%$ の割合で改善するとし，素材 としては，図3左に示すように機体のフレーム構造の約 $50 \%$ を複合材料，炭素繊維強化プラスチック（CFRP）とした ${ }^{5}$ 。 CFRPの利点は，快適性の向上（客室気圧高度の低下，客室 湿度の増加, 大型の空など), 疲労と腐食の耐久性向上, 重 量の軽減，運航寿命の長期化，部品点数の削減，製造工程時 間の削減などがあげられる。ここで興味深いことは, CFRP を用いても 787 の機体は必ずしも軽くなっていないことであ る。ANAのホームページでは, 787-8の重量（約 115 トン） は767-300ER（約90トン）に比べて約2 割増加しているにも 関わらず，燃費は約 $21 \%$ 低減したとしている。この理由は

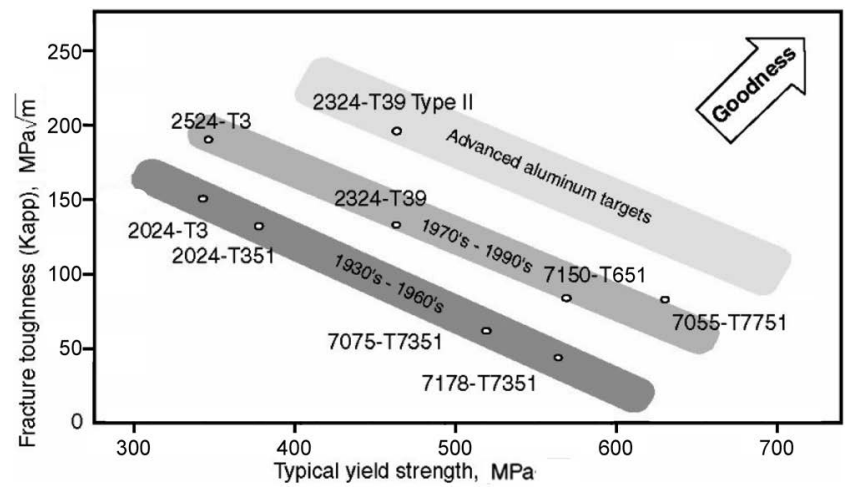

図 1 航空機用アルミニウム合金開発の高強度高勒性化 の流れ ${ }^{2}$
まずは新エンジンの効率がよいことにある。また787の重量 増加は，スパン (翼幅) が大きいことと, 航続距離を伸ばす ために燃料搭載量増加に耐える構造としたためで, これを従 来のアルミニウム構造としたらさらに重量は増加したとのこ とである ${ }^{6)}$ 。

\section{2. $3 \quad \mathrm{~A} 380$}

エアバス社は 1989 年からボーイング $747 に$ 対抗できる大型 機UHCA（Ultra High Capacity Aircraft）構想の実現を発表し, 1994 年にはA3XXとして計画を着手, 2000年A380として開 発に入った。2005年欧州航空安全機関（EASA）と米国連邦 航空局（FAA）の型式証明を同時取得し，2007年シンガポー ル航空に引き渡された。この機体は二階建ての客室を有し, 客室総面積はボーイング747-400の約 1.5 倍で, A380-800の 3 クラス（エコノミー, ビジネス，ファースト）の標準客席 数は 525 席となり，747-400の 400 席を大幅に超え世界最大の 旅客機となった ${ }^{5)}$ 。

A380の機体フレーム全体では図3 中央に示すようにアル ミニウム合金の使用比率が $61 \%$ を占めている。CFRPを含む 複合材料が $22 \%$ ，チタンとスチールが $10 \%$ ，その他 $7 \%$ とし てグレア（アルミニウム箔とガラス繊維布を積層させた複 合材料）が $3 \%$ ，その他の素材が $2 \%$ ，表面コーティング材が $2 \%$ となっている。前部胴体と後部胴体の上面および側面パ ネルにグレアが適用されている。主翼が付く中央胴体，およ び前部胴体と後部胴体の下面には圧縮応力に強いアルミニウ ム合金が用いられている。主翼も基本的にはアルミニウム 合金が用いられている。動翼の多くはCFRPだが, 前縁のド ループ・ノーズとストラット，後縁の内側フラップはアル ミニウム合金製である。Al-Li合金はメインデッキ，クロス

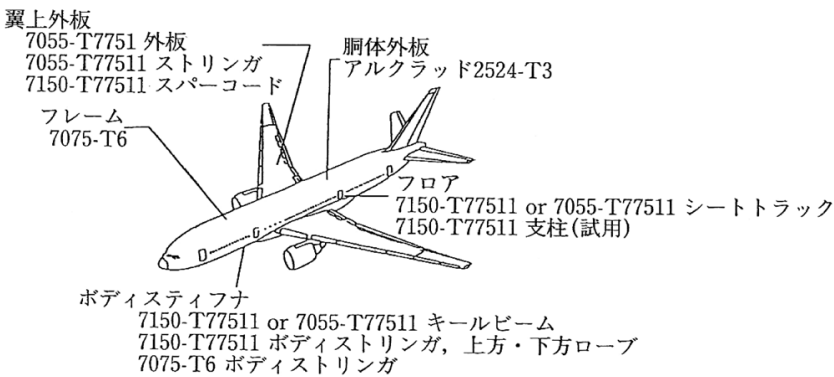

図2 ボーイング777に使用されている航空機用アルミ ニウム合金 ${ }^{3)}$
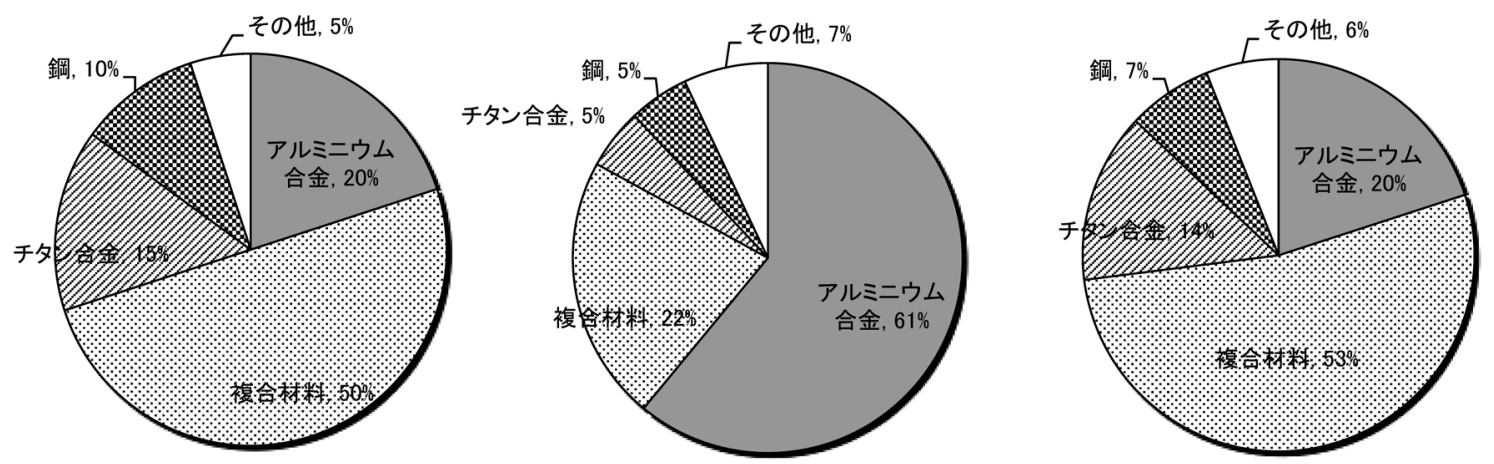

図3 ボーイング787，エアバス $\mathrm{A} 380 ， \mathrm{~A} 350 \mathrm{XWB}$ の材料構成比 ${ }^{5)}$ 
- 今後20年間の需要は、毎年約 $4 \sim 5 \%$ 増加

・ 大型リージョナル機の新規需要は5,000機

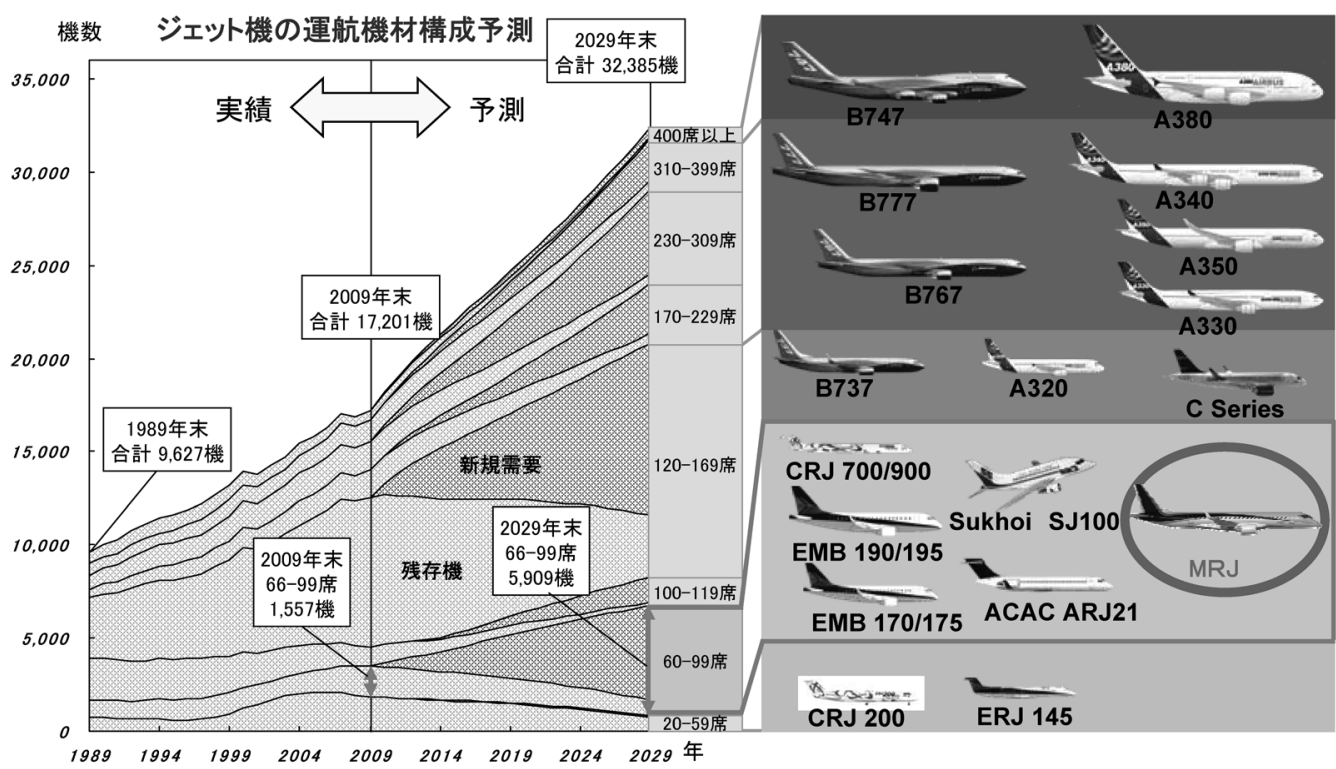

出典:MJET需要予測(2010年 2029年)

図4 座席数別のジェット旅客機の需要動向 ${ }^{14}$

ビーム，床，ストリンガに2099-T83, 2196-T8511 押出材が, 主翼の桁やリブなどの内部構造に2050-T84厚板が採用され ている ${ }^{7), 8)}$ 。尾翼は水平安定板, 垂直安定板ともにCFRP 製である。2階のデッキビームには剛性が要求されるため, CFRPが用いられている7)。

\section{4 A350XWB}

A350 は中型双発機として当初A330ベースに開発が構想さ れていたが，受注数で787に大きく水をあけられたため，再 設計しA350 XWB（eXtra Wide Body）として2006年発表さ れた。この飛行機は真円の胴体断面から太いダブルバブル 断面とすることで, 787 より多い座席数, 大きな搭載量と し，ボーイング 787 さらには777に対抗できる機種となった。 標準型の A350-900が3クラスで314席，胴体延長型の A3501000 が350席で，これに対し，ボーイングの標準型787-8で は197席，胴体延長型の 787-9では285席である。2014年 9 月 EASAの型式証明を取得し，2014年 12 月カタール航空に最 初の1機が引き渡された ${ }^{5), 9) 。 ~}$

A350XWBの大きな特徵のひとつが，787 と同様に機体構 造に $53 \%$ の複合材料を用いていることである (図 3 右 $)^{5)}$ 。胴 体の製造では，787が円筒形を一体成形するのに対し，上下 左右 4 枚の胴体パネルを製造し，それをチタン合金製ファス ナで結合する方式をとっている。コックピット周辺はバード ストライク対策のため衝撃に弱いCFRPに代わってアルミニ ウム合金が用いられている。CFRPの場合，衝撃によって炭 素繊維の層が剥がれて (層間剥離) 強度低下しても外観か

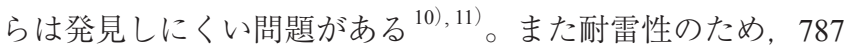
ではCFRPに銅メッシュを重ねるが，A350XWBでは銅箔を

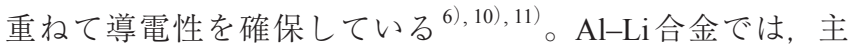
翼ボックスのリブ等に2050-T84厚板が，中央ビームに2050T852鍛造材が用いられている。主脚格納部には2198-T851板 材のロールフォーミングと切削による部品が使用されてい $b^{8)}$ 。
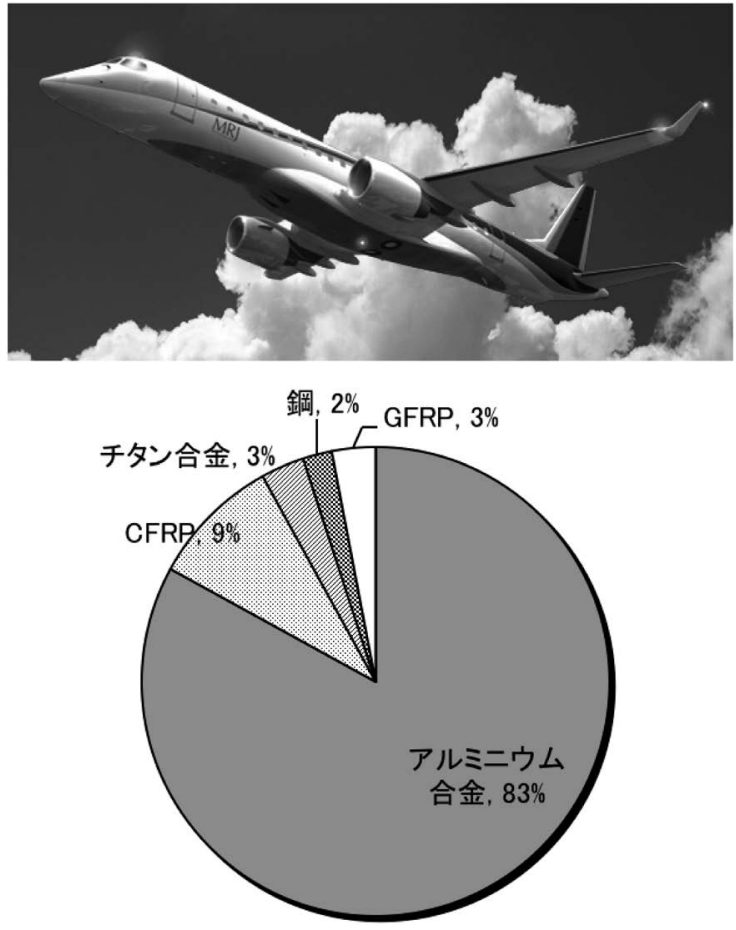

図5 MRJ とその材料構成比 ${ }^{14}$

\section{5 国産旅客機MRJの登場}

MRJ は2002 年 NEDO が提案した $30 〜 50$ 席クラスの小型 ジェット機開発「環境適応型高性能小型航空機」計画をべー スに，三菱航空機（三菱重工業の $100 \%$ 子会社，2008 年設立) が設計開発するジェット旅客機である。2015年秋に初飛行 の予定である。三菱航空機は70９0席クラスのリージョナ ルジェット機が, 今後 20 年間で 5000 機以上との需要予測の もとに 2015 年の型式証明取得から 20 年間で 1000 機以上の販

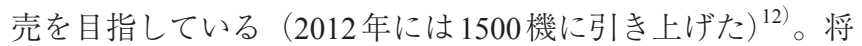


来の需要予測を図4に示す ${ }^{13) \sim 15)}$ 。この分野の航空機として はすでにカナダのボンバルディアやブラジルのエンブラエル があり，さらにロシアや中国も進出しょうとしている。

これらのライバル機に対し，MRJは70席のMRJ-70 と 90 席の MRJ-90を開発し, 燃費性能と乗客の居住性で優位性を 示すことで対抗しょうとしている。現時点でのシミュレー ションではライバル機を約 $20 \%$ 上回る結果が得られている。 当初の構想ではCFRPも用いた機体構造で $15 \%$, エンジンで $15 \%$ ，合わせて $30 \%$ の燃費向上を目指していたが，2009年に 大幅な設計変更がなされ，主翼にはCFRPから 7000 系合金を 用いることになった。この変更の理由は，次に挙げる 5 点ほ どである。

第 1 に 787 と異なり主翼面積が小さいため断面形状の曲率 は大きく，丸みを帯びたものになる。CFRPでは曲率が大き くなると，しわができやすくなり，しわができると空力特性 は大幅に下がる。しわを避けるためにシートを分割すると強 度が弱くなり, そのため積層枚数の増加や補強材追加が必要 になり軽量化効果が少なくなること ${ }^{12), 16), 17) 。 ~}$

第 2 に主翼の燃料タンクの点検口が多く, 点検口の周囲は CFRPだと補強が必要で，主翼の小さいMRJだと補強材の割 合が787に比べて大きくなり重量も増して軽量化の効果も得 られずコスト高になること ${ }^{18)}$ 。
第3にCFRPの場合は高価な成形の型を派生機ごとにつく ると費用がかさんでしまうこと ${ }^{18)}$ 。

第4に耐雷性では，CFRPを使用すると，機体に雷が落ち た場合，雷電流は炭素繊維を伝って流れ，ボルト穴で隙間 が空いていると放電する。もし主翼のボルト穴で放電現象が 起こったら, 燃料は一瞬にして爆発して, 旅客機は墜落して しまう。したがって耐雷対策を厳重に行うと余分な重量を 使用し，金属製主翼とCFRP主翼では重量はほとんど変わら ないということになり，コスト的にもメリットが出せないこ と ${ }^{19)}$ 。

第 5 に小型飛行機になると空港での地上車両等との接触の 危険性が増し，追突すれば内部欠陥となり，「CFRPだとはっ きりとした痕跡が残らないので気がつきにくい」ので見落と される可能性が高いこと览などである。

これに対しアルミニウム合金を用いると，落雷対策のため の余分な対策も不要になり, 既存の加工技術がそのまま活 かせるメリットもある。機体構造を工夫することで $5 \%$ の燃 費削減が図られたと推定されている。エンジンでは P\&Wの GTF（Geared Turbo Fan）という新型エンジンを用いること で然費を約 $16 \%$ 削減できる。図 5 にMRJの外観とその材料 構成比を示す ${ }^{13)}$, 14)。しかし, 今後, 燃費削減がさらに要求 されると，開発が予定されている MRJ-100では主翼のアルミ
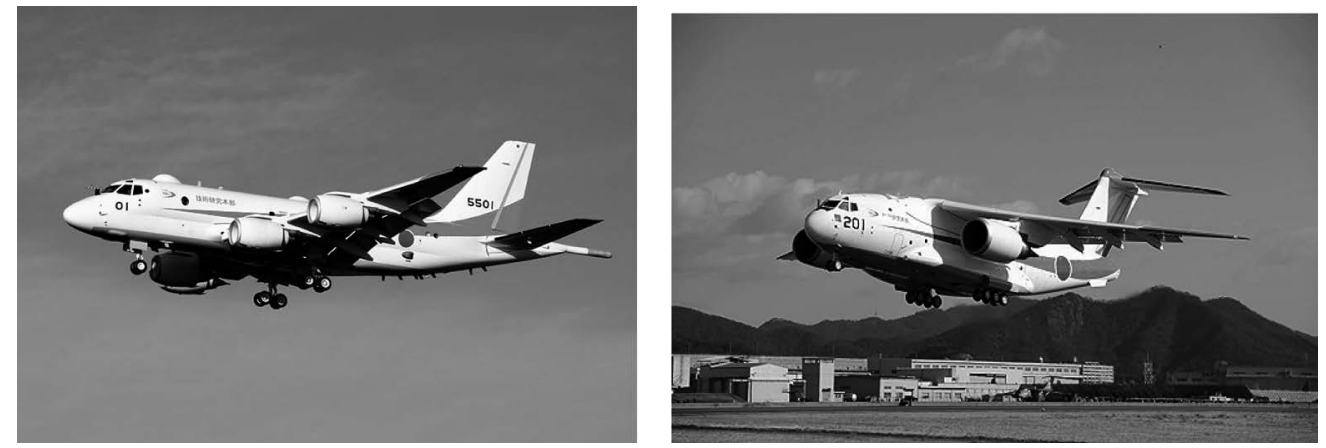

図6 対潜哨戒機 P-1（左）と大型輸送機 C-2（右 $)^{22)}$

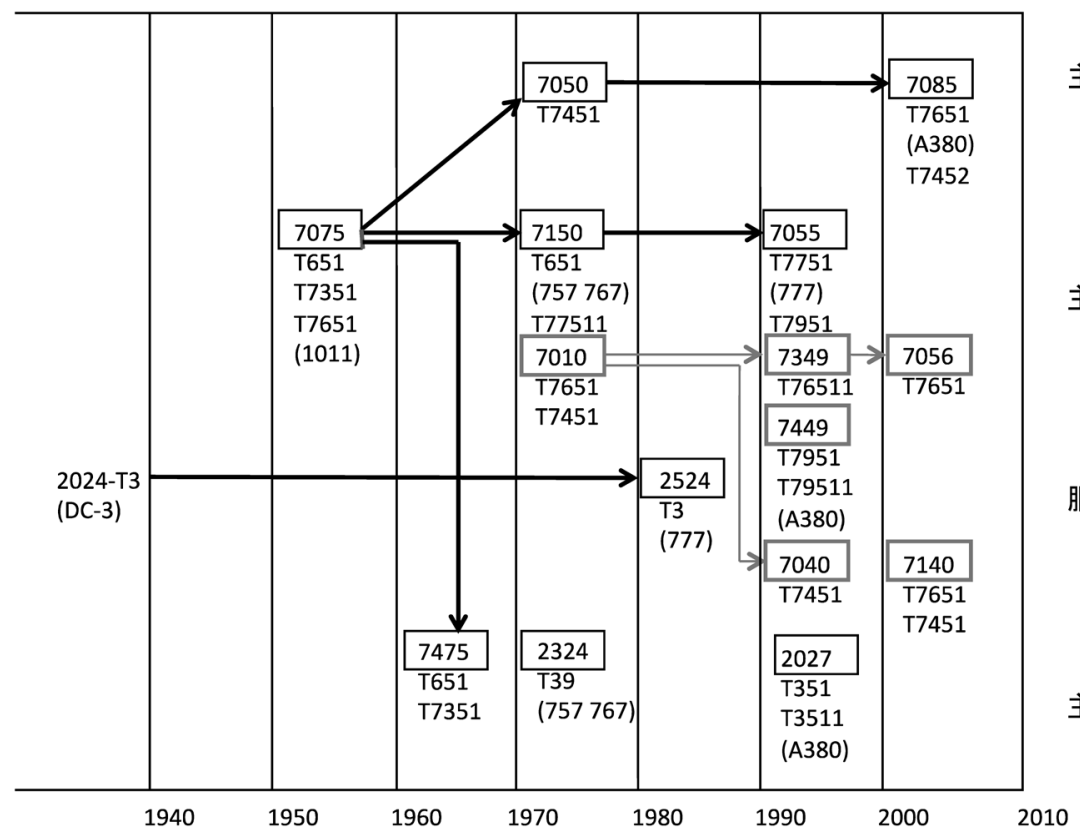

主翼桁/リブ

厚板構造

主翼上面外板

縦通材

胴体構造

主翼下面外板

縱通材

図7 航空機の部位と開発されたアルミニウム合金の関係 ${ }^{13)}$ 
表2 AAに登録されている航空機用アルミニウム合金の成分 $(\mathrm{Li} \text { 含有合金を除く })^{23)}$

\begin{tabular}{|c|c|c|c|c|c|c|c|c|c|c|c|c|}
\hline No. & Date & By & $\mathrm{Si}$ & $\mathrm{Fe}$ & $\mathrm{Cu}$ & $\mathrm{Mn}$ & $\mathrm{Mg}$ & $\mathrm{Cr}$ & $\mathrm{Zn}$ & $\mathrm{Zr}$ & $\mathrm{Ti}$ & \\
\hline 2013 & 2003 & JAPAN & $0.6-1.0$ & 0.40 & $1.5-2.0$ & 0.25 & $0.8-1.2$ & $0.04-0.35$ & 0.25 & & 0.15 & \\
\hline 2014 & 1954 & USA & $0.50-1.2$ & 0.7 & $3.9-5.0$ & $0.40-1.2$ & $0.20-0.8$ & 0.10 & 0.25 & $0.20 \mathrm{Zr}+\mathrm{Ti}$ & 0.15 & \\
\hline 2017 & 1954 & USA & $0.20-0.8$ & 0.70 & $3.5-4.5$ & $0.40-1.0$ & $0.40-0.8$ & 0.10 & 0.25 & & 0.15 & \\
\hline 2024 & 1954 & USA & 0.50 & 0.50 & $3.8-4.9$ & $0.30-0.9$ & $1.2-1.8$ & 0.10 & 0.25 & $0.20 \mathrm{Zr}+\mathrm{Ti}$ & 0.15 & \\
\hline 2124 & 1970 & USA & 0.20 & 0.30 & $3.8-4.9$ & $0.30-0.9$ & $1.2-1.8$ & 0.10 & 0.25 & $0.20 \mathrm{Zr}+\mathrm{Ti}$ & 0.15 & \\
\hline 2424 & 1994 & USA & 0.10 & 0.12 & $3.8-4.4$ & $0.30-0.6$ & $1.2-1.6$ & & 0.20 & & 0.10 & \\
\hline 2524 & 1995 & USA & 0.06 & 0.12 & $4.0-4.5$ & $0.45-0.7$ & $1.2-1.6$ & 0.05 & 0.15 & & 0.10 & \\
\hline 2624 & 2009 & USA & 0.08 & 0.08 & $3.8-4.3$ & $0.45-0.7$ & $1.2-1.6$ & 0.05 & 0.15 & & 0.10 & \\
\hline 2025 & 1954 & USA & $0.50-1.2$ & 1.0 & $3.9-5.0$ & $0.40-1.2$ & 0.05 & 0.10 & 0.25 & & 0.15 & \\
\hline 2026 & 1996 & USA & 0.05 & 0.07 & $3.6-4.3$ & $0.30-0.8$ & $1.0-1.6$ & & 0.10 & $0.05-0.25$ & 0.06 & \\
\hline 2027 & 2001 & FRANCE & 0.12 & 0.15 & $3.9-4.9$ & $0.50-1.2$ & $1.0-1.5$ & & 0.20 & $0.05-0.15$ & 0.08 & \\
\hline 2056 & 2003 & FRANCE & 0.10 & 0.12 & $3.3-4.3$ & $0.10-0.50$ & $0.6-1.4$ & & $0.40-0.8$ & & & \\
\hline 2219 & 1954 & USA & 0.20 & 0.30 & $5.8-6.8$ & $0.20-0.40$ & 0.02 & & 0.10 & $0.10-0.25$ & $0.02-0.10$ & $0.05-0.15 \mathrm{~V}$ \\
\hline 2519 & 1985 & USA & 0.25 & 0.30 & $5.3-6.4$ & $0.10-0.50$ & $0.05-0.40$ & & 0.10 & $0.10-0.25$ & $0.02-0.10$ & $0.05-0.15 \mathrm{~V}$ \\
\hline 2618 & 1954 & USA & $0.10-0.25$ & $0.9-1.3$ & $1.9-2.7$ & & $1.3-1.8$ & & 0.10 & & $0.04-0.10$ & $0.9-1.2 \mathrm{Ni}$ \\
\hline 7010 & 1975 & UK & 0.12 & 0.15 & $1.5-2.0$ & 0.10 & $2.1-2.6$ & 0.05 & $5.7-6.7$ & $0.10-0.16$ & 0.06 & \\
\hline 7136 & 2004 & USA & 0.12 & 0.15 & $1.9-2.5$ & 0.05 & $1.8-2.5$ & 0.05 & $8.4-9.4$ & $0.10-0.20$ & 0.10 & \\
\hline 7037 & 2006 & GERMANY & 0.10 & 0.10 & $0.6-1.1$ & 0.50 & $1.3-2.1$ & 0.04 & $7.8-9.0$ & $0.06-0.25$ & 0.10 & \\
\hline 7040 & 1996 & FRANCE & 0.10 & 0.13 & $1.5-2.3$ & 0.04 & $1.7-2.4$ & 0.04 & $5.7-6.7$ & $0.05-0.12$ & 0.06 & \\
\hline 7140 & 2005 & FRANCE & 0.10 & 0.13 & $1.3-2.3$ & 0.04 & $1.5-2.4$ & 0.04 & $6.2-7.0$ & $0.05-0.12$ & 0.06 & \\
\hline 7049 & 1968 & USA & 0.25 & 0.35 & $1.2-1.9$ & 0.20 & $2.0-2.9$ & $0.10-0.22$ & $7.2-8.2$ & & 0.10 & \\
\hline 7149 & 1975 & USA & 0.15 & 0.20 & $1.2-1.9$ & 0.20 & $2.0-2.9$ & $0.10-0.22$ & $7.2-8.2$ & & 0.10 & \\
\hline 7249 & 1982 & USA & 0.10 & 0.12 & $1.3-1.9$ & 0.10 & $2.0-2.4$ & $0.12-0.18$ & $7.5-8.2$ & & 0.06 & \\
\hline 7349 & 1994 & FRANCE & 0.12 & 0.15 & $1.4-2.1$ & 0.20 & $1.8-2.7$ & $0.10-0.22$ & $7.5-8.7$ & $0.25 \mathrm{Zr}+\mathrm{Ti}$ & & \\
\hline 7449 & 1994 & FRANCE & 0.12 & 0.15 & $1.4-2.1$ & 0.20 & $1.8-2.7$ & & $7.5-8.7$ & $0.25 \mathrm{Zr}+\mathrm{Ti}$ & & \\
\hline 7050 & 1971 & USA & 0.12 & 0.15 & $2.0-2.6$ & 0.10 & $1.9-2.6$ & 0.04 & $5.7-6.7$ & $0.08-0.15$ & 0.06 & \\
\hline 7150 & 1978 & USA & 0.12 & 0.15 & $1.9-2.5$ & 0.10 & $2.0-2.7$ & 0.04 & $5.9-6.9$ & $0.08-0.15$ & 0.06 & \\
\hline 7055 & 1991 & USA & 0.10 & 0.15 & $2.0-2.6$ & 0.05 & $1.8-2.3$ & 0.04 & $7.6-8.4$ & $0.08-0.25$ & 0.06 & \\
\hline 7255 & 2009 & USA & 0.06 & 0.09 & $2.0-2.6$ & 0.05 & $1.8-2.3$ & 0.04 & $7.6-8.4$ & $0.08-0.15$ & 0.06 & \\
\hline 7056 & 2004 & FRANCE & 0.10 & 0.12 & $1.2-1.9$ & 0.20 & $1.5-2.3$ & & $8.5-9.7$ & $0.05-0.15$ & 0.08 & \\
\hline 7068 & 1996 & USA & 0.12 & 0.15 & $1.6-2.4$ & 0.10 & $2.2-3.0$ & 0.05 & $7.3-8.3$ & $0.05-0.15$ & 0.10 & \\
\hline 7075 & 1954 & USA & 0.40 & 0.50 & $1.2-2.0$ & 0.30 & $2.1-2.9$ & $0.18-0.28$ & $5.1-6.1$ & $0.25 \mathrm{Zr}+\mathrm{Ti}$ & 0.20 & \\
\hline 7175 & 1957 & USA & 0.15 & 0.20 & $1.2-2.0$ & 0.10 & $2.1-2.9$ & $0.18-0.28$ & $5.1-6.1$ & & 0.10 & \\
\hline 7475 & 1969 & USA & 0.10 & 0.12 & $1.2-1.9$ & 0.06 & $1.9-2.6$ & $0.18-0.25$ & $5.2-6.2$ & & 0.06 & \\
\hline 7085 & 2002 & USA & 0.06 & 0.08 & $1.3-2.0$ & 0.04 & $1.2-1.8$ & 0.04 & $7.0-8.0$ & $0.08-0.15$ & 0.06 & \\
\hline ESD & 1936 & JAPAN & & & $1.5-2.5$ & $0.3-1.0$ & $1.2-1.8$ & $0.1-0.4$ & $6.0-9.0$ & & & \\
\hline
\end{tabular}

ニウム合金がCFRPになる可能性もある ${ }^{16)}$ 。

\section{6 Honda Jet}

2015 年 4 月, 日本公開されたHonda Jet は乗員含めて7名乗 りの小型ビジネスジェットで, ノースカロライナ州グリーン ズボロ市にあるピードモント・トライアッド国際空港内のホ ンダ・エアクラフト・カンパニーの工場で生産が行われてい る。この Honda Jetでは，エンジンを主翼上面に配置し，空 力的にも大きな効果を得る最適な位置と形状を備えたユニー クな主翼上面形態にしている。この形態では胴体後部のエン ジン支持構造が不要で内部スペースを最大限に利用できるた め，広い客席と大きな荷物室が実現できた。胴体の組立てに おいては，CFRP複合材料を用いてハニカムサンドイッチパ ネルとスティフンドパネルの2種の構造様式を組み合わせて 一体成型する製造技術により製造されている。主翼はアルミ ニウム一体削り出しスキン（外板）を用いて凹凸を極小にし

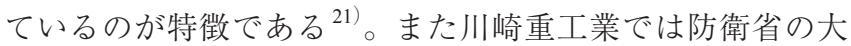

表 3 航空機各部位に要求される特性 ${ }^{7}$

\begin{tabular}{|c|c|c|}
\hline \multicolumn{2}{|c|}{ 機体の部位 } & 要求特性 \\
\hline 胴体／与圧客室 & $\begin{array}{l}\text { 下面外板 } \\
\text { 上面外板 } \\
\text { ストリンガ/フレーム } \\
\text { シート/貨物軌道 } \\
\text { 床ビーム }\end{array}$ & $\begin{array}{l}\text { CYS, E, Corrosion } \\
\text { DT, TS } \\
\text { CYS, E, DT, TS } \\
\text { TS, Corrosion } \\
\text { E, TS }\end{array}$ \\
\hline 主翼上面 (圧縮) & $\begin{array}{l}\text { 外板/ストリンガ } \\
\text { 桁 }\end{array}$ & $\begin{array}{l}\text { CYS, E, DT, TS } \\
\text { CYS, E, Corrosion }\end{array}$ \\
\hline 主翼下面 (引張) & 外板/桁/ストリンガ & DT, TS \\
\hline 水平安定板 & $\begin{array}{l}\text { 下面（圧縮） } \\
\text { 上面（引張） }\end{array}$ & $\begin{array}{l}\text { CYS, E, DT } \\
\text { DT, TS }\end{array}$ \\
\hline
\end{tabular}

CYS : 圧縮耐力, $\mathrm{E}$ : 弾性率, TS : 引張強さ,

DT：損傷許容（疲労, 疲労き裂進展, 破壊靱性) 
表 4-1 MMPDSに登録されている航空機用2000系合金の特徴, 使用形態, 調質 ${ }^{24)}$

\begin{tabular}{|c|c|c|c|}
\hline 合金 & 特徵 & 形態 & 調質 \\
\hline 2013 & 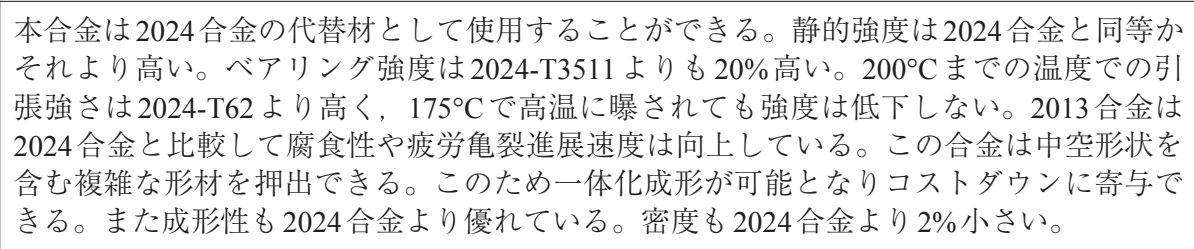 & $\begin{array}{l}\text { 押出棒, } \\
\text { 押出形材 } \\
\text { 引抜管 }\end{array}$ & T6511 \\
\hline 2014 & $\begin{array}{l}\text { 本合金は広範囲な製品で利用されている。2014-T6圧延材，棒材，形材，鍛造品のST方 } \\
\text { 向のSCC 性はDランクである。これは最も悪いレベルで使用中にSCCが発生するか，何 } \\
\text { かしらの付加応力が働く場合にはSCCが発生することを予期したほうがよい。 }\end{array}$ & $\begin{array}{l}\text { 薄板, 厚板, } \\
\text { クラッド板, } \\
\text { 押出棒, } \\
\text { 引抜棒, } \\
\text { 鍛造材 }\end{array}$ & $\begin{array}{l}\text { T6,T62, T651, } \\
\text { T652, T6510, } \\
\text { T6511 }\end{array}$ \\
\hline 2017 & 本合金は棒材や線材, 特にファスナ材として用いられている。 & 棒, 引抜棒 & $\mathrm{T} 4, \mathrm{~T} 451, \mathrm{~T} 42$ \\
\hline 2024 & 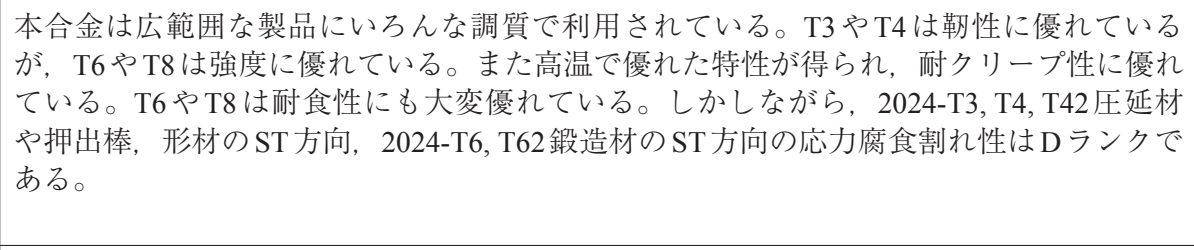 & $\begin{array}{l}\text { 薄板, 厚板, } \\
\text { クラッド板, } \\
\text { 押出棒, } \\
\text { 引抜棒, 管, } \\
\text { 押出形材 }\end{array}$ & $\begin{array}{l}\text { T3, T351, } \\
\text { T3510, T3511, } \\
\text { T4, T42, T361, } \\
\text { T62, T72, T81, } \\
\text { T851, T8510, } \\
\text { T8511, T861 }\end{array}$ \\
\hline 2124 & $\begin{array}{l}\text { 本合金は1〜6インチ厚の厚板で使用される。2024合金を高純度化した合金で特殊な工程 } \\
\text { で製造すると, 通常の製造法の2024合金よりも肉厚方向の延性と破壊鞁性が向上する。 } \\
\text { この合は T851調質のみで製造されている。2024合金と同様に高温で優れた特性と耐ク } \\
\text { リープ性を有する。T } 851 \text { 調質は耐応力腐食割れ性にも優れている。 }\end{array}$ & 厚板 & T851 \\
\hline 2424 & $\begin{array}{l}\text { 本合金は2024合金よりも延性に優れている。2424合金は裸板やクラッド板で利用されて } \\
\text { いる。 }\end{array}$ & 薄板 & T3 \\
\hline 2524 & $\begin{array}{l}\text { 本合金は他の } 2 X X X \text { 板材よりも高勒性で疲労き裂進展抵抗が優れている。板材はT3で使 } \\
\text { 用される。Alclad 2524-T3の機械的性質や一般耐食性はAlclad 2024-T3と同等である。こ } \\
\text { の合金の製品は主にAlclad 2024-T3 と同等の強度で疲労き裂進展抵抗や勒性を向上させた } \\
\text { い成形用航空機部品に用いられる。 }\end{array}$ & クラッド板 & T3 \\
\hline 2624 & $\begin{array}{l}\text { 本合金は高強度で損傷許容性に優れている。2624合金はT39, T351厚板で使用される。成 } \\
\text { 分と製造工程を最適化することで，通常の2XXX合金よりも損傷許容性に優れる。 }\end{array}$ & 厚板 & T39, T351 \\
\hline 2025 & 本合金は鍛造用合金で, 特にプロペラ材に限定されている。 & 型鍛造品 & T6 \\
\hline 2026 & $\begin{array}{l}\text { 本合金は押出棒, 形材で用いられている。この合金押出材は, 通常溶接はしないが, 加 } \\
\text { 工時に割れが生じやすい部品や切削時に極端に歪みやすい部品, 高強度で損傷許容性が } \\
\text { 必要な部品に用いられる。ある工程手順では応力腐食割れに敏感になるときがある。 }\end{array}$ & $\begin{array}{l}\text { 押出棒, } \\
\text { 押出形材 }\end{array}$ & T3511 \\
\hline 2027 & $\begin{array}{l}\text { 本合金は高強度で高損傷許容性を両立させる目的で開発された。高純度地金を用い, マ } \\
\text { グネジム, マンガン量, ジルコ系分散相の量を最適化したために, 静的特性 } \\
\text { および破壊鞁性は従来の2000系合金より優れている。本合金は2027-T351厚板, 2027- } \\
\text { T3511押出材で使用されている。2027-T351厚板は主翼下面に, 2027-T3511押出材は切削 } \\
\text { 工程での寸法安定性や高強度で高損傷許容性が必要とされる切削部品に主に用いられる。 }\end{array}$ & $\begin{array}{l}\text { 厚板, } \\
\text { 押出形材 }\end{array}$ & T351, T3511 \\
\hline $\begin{array}{c}2056 \\
\text { クラッド }\end{array}$ & $\begin{array}{l}\text { 本合金は Al-Cu-Mg-Zn 合金で, 他の 2X24板材と比較して, 耐疲労き裂進展特性, 高強 } \\
\text { 度で破壊勒性に優れている。Alclad T3板として用いられる。静的な機械的性質は Alclad } \\
\text { 2024-T3より優れている。亜鉛は, 芯材と通常のAA1050クラッド皮材との電位差を最適 } \\
\text { 化し, クラッド材の寿命を高めるために添加されている。Alclad } 2056 \text { は, 主に胴体構造 } \\
\text { の成形部品に用いられる。 }\end{array}$ & 薄板 & T3 \\
\hline 2219 & $\begin{array}{l}\text { 本合金は広範囲な製品で利用されている。2219-T351X, -T37圧延材, 押出形材の ST方向 } \\
\text { SCC 性は D クラスである。比較的高温 }\left(204 \sim 316^{\circ} \mathrm{C}\right) \text { で強度や耐クリーブ性が必要とさ } \\
\text { れる部材や極低温での用途に用いられる。 }\end{array}$ & $\begin{array}{l}\text { 薄板, 厚板, } \\
\text { 押出材, } \\
\text { 自由鍛造材 }\end{array}$ & $\begin{array}{l}\text { T62, T81, T851, } \\
\text { T8510, T8511, } \\
\text { T852, T87 }\end{array}$ \\
\hline 2519 & $\begin{array}{l}\text { 本合金は溶接が可能な } \mathrm{Al}-\mathrm{Cu} \text { 合金で厚板で使用される。防弾用板は7039合金と同等な防 } \\
\text { 弾特性を有し，5083 合金よりも耐 SCC 性に優れる。2519合金の一般耐食性は2219 と同等 } \\
\text { である。2519-T87の耐力は2219-T87材よりも20\%高い。2519-T87材は溶加材2319で容易 } \\
\text { に溶接できる。溶接部の耐力は他の溶接できる合金よりも高い。2519合金は溶接後時効, } \\
\text { あるいは溶接後焼入れ時効することで溶接ままの態よりも機械的性質が向上する。 }\end{array}$ & 厚板 & T87 \\
\hline 2618 & $\begin{array}{l}\text { 本合金は自由鍛造や型鍛造に用いられている。 }-269 \sim 316^{\circ} \mathrm{C} \text { の温度範囲で優れた特性を } \\
\text { 有し, 高強度と耐クリープが重要な用途に用いられる。 }\end{array}$ & $\begin{array}{l}\text { 自由鍛造品, } \\
\text { 型鍛造品 }\end{array}$ & T61 \\
\hline
\end{tabular}


表 4-2 MMPDSに登録されている航空機用7000系合金の特徵, 使用形態, 調質 (その1 $)^{24)}$

\begin{tabular}{|c|c|c|c|}
\hline 合金 & 特徵 & 形態 & 調質 \\
\hline 7010 & 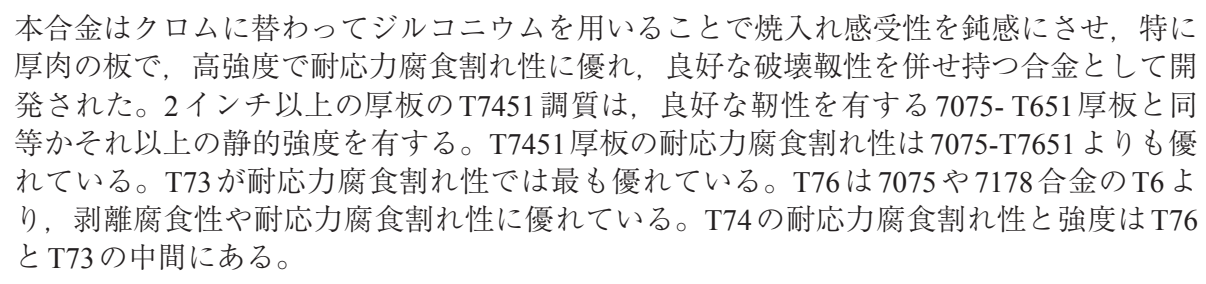 & 厚板 & $\mathrm{T} 7451, \mathrm{~T} 7651$ \\
\hline 7136 & $\begin{array}{l}\text { 本合金は良好な高強度と耐食性を兼ね備えた合金である。剥離腐食性と耐応力腐食割れ性 } \\
\text { は他の7XXX-T76合金と同等である。 }\end{array}$ & 押出材 & T76511 \\
\hline 7037 & $\begin{array}{l}\text { 本合金は従来の7XXX合金の強度と破壊勒性を向上させた合金である。焼入れ感受性を鈍 } \\
\text { 感にするよう合金成分を最適化させていて, ランディングギア用鍛造品, フレーム, スパ, } \\
\text { フィッティングなどのような大きな肉厚を有する部品や大きな鍛造品に有効である。7037 } \\
\text { 合金は4インチ (100 mm) 以上の厚みを有する自由鍛造品や型鍛造品で高強度高破壊鞁性 } \\
\text { を示す。 }\end{array}$ & 自由鍛造品 & $\mathrm{T} 7452$ \\
\hline 7040 & $\begin{array}{l}\text { 本合金は通常利用されている7010や7050合金よりも, 特に } 8.5 \text { インチまでの厚板で高強度 } \\
\text { 高勒性が得られるように開発された合金である。ジルコニウム, 不純物, マグネシウム, } \\
\text { 銅量を適正化して7050合金よりも焼入れ受性を鈍くし, 非常に厚い板でも高強度高勒 } \\
\text { 性が得られる。7040-T7451厚板は高強度高勒性高耐食性が要求される構造物には適してい } \\
\text { る。切削加工で一体化加工したスパ (桁), リブ (小骨), 胴体フレームなどの部品には有 } \\
\text { 用である。7040合金は3.0 8.5インチの厚板材にも使用されている。残留応力を厳しく制 } \\
\text { 御しているので, 極めて寸法安定性がよい。このため切削後のひずみ矯正が必要とされる } \\
\text { 圧延材や鍛造材ではこれを使用することでコスト低減になる。 }\end{array}$ & 厚板 & $\mathrm{T} 7451$ \\
\hline 7140 & $\begin{array}{l}\text { 本合金は7 } 7040 \text { 合金の派生型で非常に厚い板に用いられる。7040合金よりも高強度で勒性 } \\
\text { がある。強度, 破壊靱性と耐食性のバランスを考慮したT7451 と T7651の2 種類の調質で } \\
\text { 製造される。応力腐食割れ性と剥離腐食性は7XXX系合のこのクラスの } 77451, \mathrm{~T} 7651 \text { 調 } \\
\text { 質と同等である。 }\end{array}$ & 厚板 & $\mathrm{T} 7451, \mathrm{~T} 7651$ \\
\hline $\begin{array}{l}7049 / \\
7149\end{array}$ & $\begin{array}{l}\text { 本系合金は型鍛造品, 自由鍛造品, 押出材で使用されている。7149合金は7049合金の鉄, } \\
\text { けい素量を低隇させた合金である。T73XX調質は良好な静的強度と耐応力腐食割れ性に } \\
\text { 優れた特性を有する。T73XX調質の疲労強度は7075-T6とほぼ同程度であり, 勒性はやや } \\
\text { 高い。 }\end{array}$ & $\begin{array}{l}\text { 鍛造品, } \\
\text { 押出材, } \\
\text { 厚板 }\end{array}$ & $\mathrm{T} 73, \mathrm{~T} 73511$ \\
\hline 7249 & 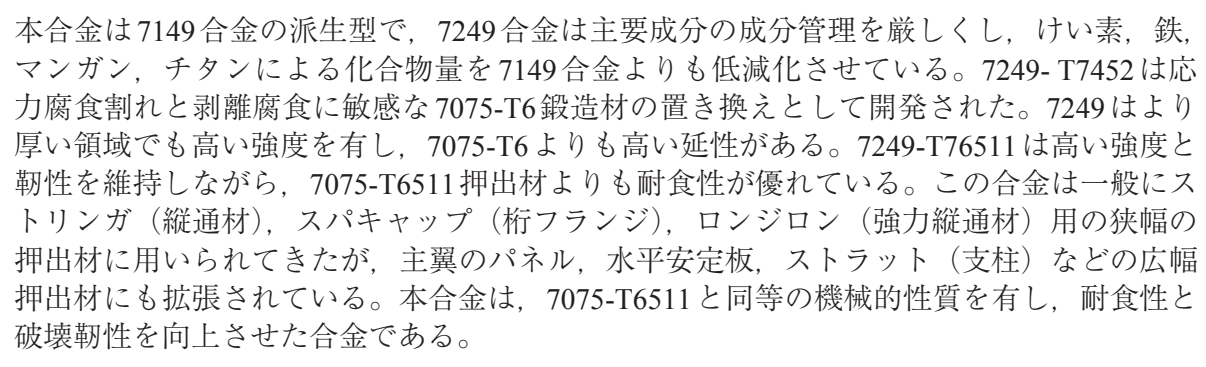 & $\begin{array}{l}\text { 自由鍛造品, } \\
\text { 押出材 }\end{array}$ & T7452, T76511 \\
\hline 7349 & $\begin{array}{l}\text { 本合金は } 7150 \text { 合金と同等の強度を有し, 小型から中型の押出材に使用されている。 } \\
\mathrm{T} 76511 \text { 調質は高い引張強さと過時効材と同等のレベルの剥離腐食性を有している。 }\end{array}$ & 押出形材 & $\mathrm{T} 76511$ \\
\hline 7449 & $\begin{array}{l}\text { 本合金は従来の7XXX系合金より高強度である。7449合金は板では2種類の調質, 押出材 } \\
\text { では } 1 \text { 種類の調質で使用されている。T7951調質は高い引張や圧縮特性, ほどほと破壊 } \\
\text { 鞁性, 過時効材と同等なレベルで定量化可能なレベルの耐応力腐食割れ性を示す。T7651 } \\
\text { 調質は, 他の7XXX系合金のT76調質と比較して, 引張強さは低いがほどぼの破壊䩲性 } \\
\text { を有し耐応力腐食割机性は優れている。 }\end{array}$ & $\begin{array}{l}\text { 厚板, } \\
\text { 押出形材 }\end{array}$ & $\begin{array}{l}\text { T7651, T7951, } \\
\text { T79511 }\end{array}$ \\
\hline 7050 & 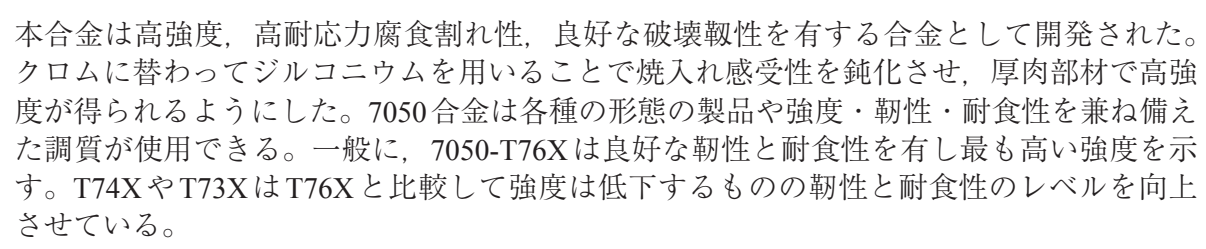 & $\begin{array}{l}\text { 厚板, } \\
\text { 自由鍛造品, } \\
\text { 型錹造品, } \\
\text { 押出形材 }\end{array}$ & $\begin{array}{l}\text { T73510, } \\
\text { T73511, T74, } \\
\text { T7451, T7452, } \\
\text { T76510, } \\
\text { T76511 }\end{array}$ \\
\hline
\end{tabular}


表4-3 MMPDSに登録されている航空機用7000系合金の特徵, 使用形態, 調質 $(\text { その } 2)^{24)}$

\begin{tabular}{|c|c|c|c|}
\hline 合金 & 特徴 & 形態 & 調質 \\
\hline 7150 & $\begin{array}{l}\text { 本合金は第二世代の } 7050 \text { 合金で, } 3 \text { インチまでの厚みで高強度が得られる。本合金は厚板 } \\
\text { や押出材として用いられる。T61 は厚板の破壊鞁性值を保証して高強度が得られる。T77 } \\
\text { は勒性と耐食性を保証して高強度が得られる。T77 } 7 \text { 他の } 7000 \text { 系合金の } 776 \text { と同等の剥離 } \\
\text { 腐食性と耐応力腐食割れ性を示す。 }\end{array}$ & $\begin{array}{l}\text { 厚板, } \\
\text { 押出材 }\end{array}$ & $\begin{array}{l}\text { T6151, T61511, } \\
\text { T7751, T77511 }\end{array}$ \\
\hline 7055 & $\begin{array}{l}\text { 本合金は } 7150 \text { 合金よりも高強度を示す。本合金は薄板, 厚板, 押出材で使用される。T77 } \\
\text { は勒性 (厚板のみ) と耐剥離腐食性を保証し, 高い引張および圧縮強度が得られる。T77 } \\
\text { は他の7XXX系合金のT76タイプの調質と同等の耐剥離腐食性を有する。 }\end{array}$ & $\begin{array}{l}\text { 薄板, } \\
\text { 厚板, } \\
\text { 押出材 }\end{array}$ & $\begin{array}{l}\text { T74511, } \\
\text { T76511, T7751, } \\
\text { T77511, T762 }\end{array}$ \\
\hline 7255 & $\begin{array}{l}\text { 本合金は損傷許容性が同等あるいはそれ以上を有する7XXX合金よりも強度と疲労強度が } \\
\text { 高い。本合金は厚板で使用される。T77は他の7XXX合金のT76に比べて引張および圧縮 } \\
\text { 強度が高い。7225厚板は主に主翼上面パネルに使用されている。 }\end{array}$ & 厚板 & $\mathrm{T} 7751$ \\
\hline 7056 & $\begin{array}{l}\text { 7056-T7651主翼上面のような比較的薄い厚板に使用されている。7056合金は高い引張拉 } \\
\text { よび圧縮特性とほどどの耐食性を有し, 破壊鞁性を向上させるために全最適 } \\
\text { 化と拡張をった合金である。応力腐食割れ性と剥離腐食性はこのクラスの7XXX系合金 } \\
\text { T7651 と同等である。 }\end{array}$ & 厚板 & $\mathrm{T} 7651$ \\
\hline 7068 & 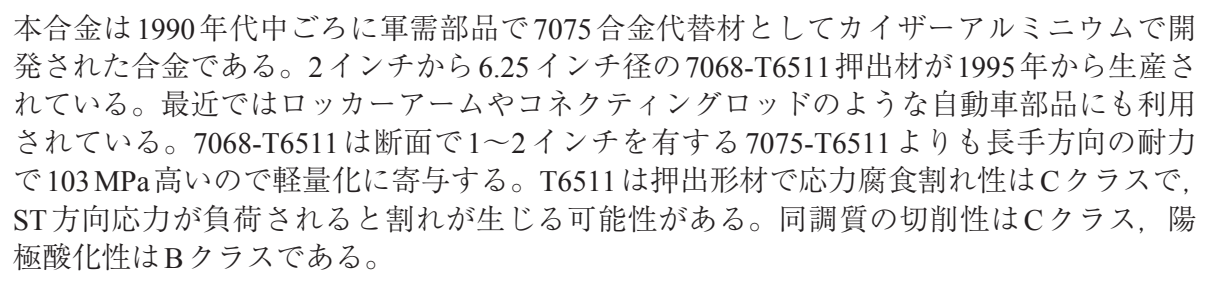 & 押出材 & $\mathrm{T} 6511$ \\
\hline 7075 & 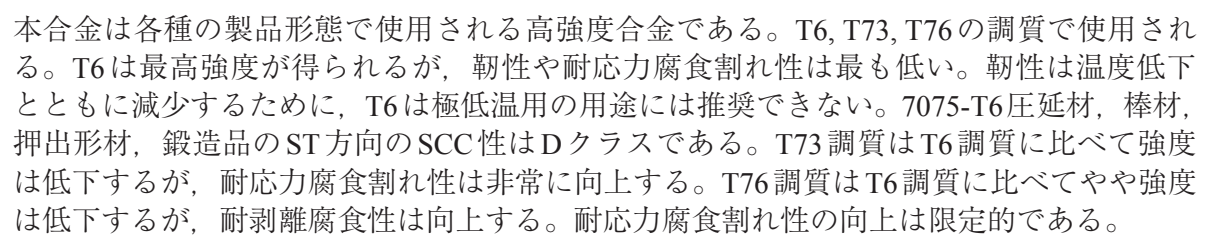 & $\begin{array}{l}\text { 薄板, 厚板, } \\
\text { クラッド板, } \\
\text { 棒, 引抜棒, } \\
\text { 押出棒, } \\
\text { 押出形材, } \\
\text { 型鍛造品 }\end{array}$ & $\begin{array}{l}\text { T6, T651, T652, } \\
\text { T6510, T6511, } \\
\text { T73, T7351, } \\
\text { T7352, T73510, } \\
\text { T73511 }\end{array}$ \\
\hline 7175 & 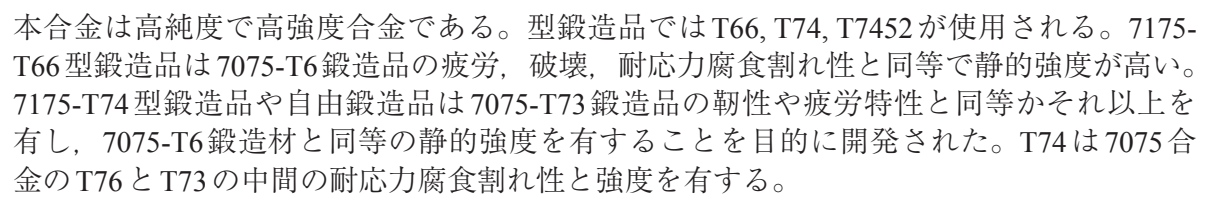 & $\begin{array}{l}\text { 型鍛造品, } \\
\text { 自由鍛造品, } \\
\text { 押出 }\end{array}$ & $\begin{array}{l}\text { T73511, T74, } \\
\text { T7452 }\end{array}$ \\
\hline 7475 & 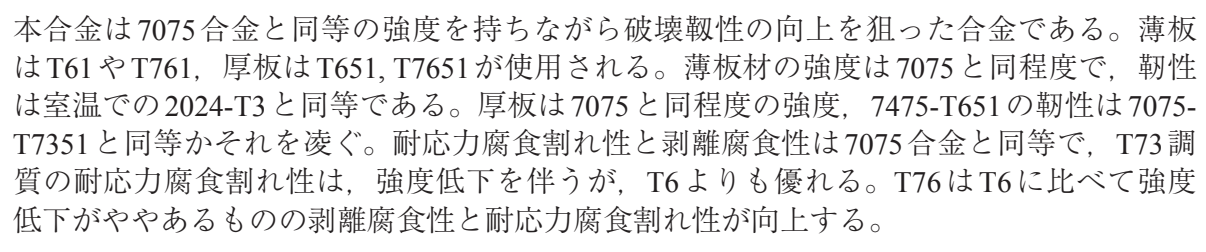 & $\begin{array}{l}\text { 薄板, } \\
\text { 厚板, } \\
\text { クラッド板 }\end{array}$ & $\begin{array}{l}\text { T61, T651, } \\
\text { T7351, T761, } \\
\text { T7651 }\end{array}$ \\
\hline 7085 & 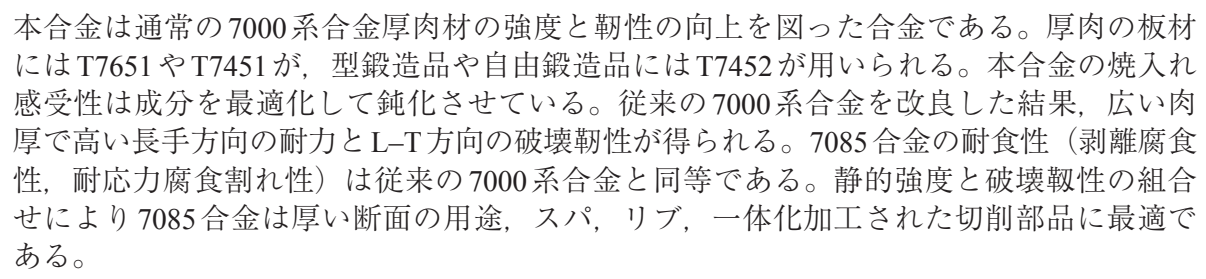 & $\begin{array}{l}\text { 厚板, } \\
\text { 型鍛造品, } \\
\text { 自由鍛造品 }\end{array}$ & T7651, T7452 \\
\hline
\end{tabular}

型輸送機（C-2）や対潜哨戒機（P-1）（図6）を製造するこ とで機体の設計製造がすべて国産化できる状況になってきて いる ${ }^{22)}$ 。この技術を民間機に転用し世界に販売して行くこ とも日本の技術力を上げていくことに繋がると考えられる。

\section{3. 最近の航空機用アルミニウム合金の動向}

\subsection{0 系, 7000 系合金（Li含有合金をのぞく）}

図7に示すように2000年以降の航空機に, 主翼桁やリブ に7085 合金, 主翼上面に7056合金, 胴体構造に7140合金

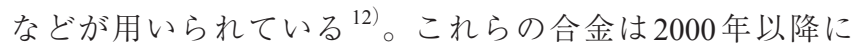


表 5 MRJの基本材料 (ベースライン) と今後使用される候補材料 ${ }^{13}$

\begin{tabular}{|c|c|c|c|c|c|}
\hline \multicolumn{2}{|r|}{ 部 } & ベースライン & \multicolumn{3}{|c|}{ 候補材料 } \\
\hline \multirow{2}{*}{ 主翼上面 } & 板 & $7075-\mathrm{T} 651$ & $\begin{array}{l}\text { 7075-T7351 } \\
\text { 7055-T7751 (B777) } \\
7449-\mathrm{T} 7951\end{array}$ & $\begin{array}{l}\text { 7150-T7751 } \\
\text { 7055-T7951 (A390) } \\
\text { 7056-T7951 }\end{array}$ & \\
\hline & 押出材 & 7075-T6511 & $\begin{array}{l}\text { 7075-T73511 } \\
\text { 7055-T77511 (B777) } \\
7349-\mathrm{T} 76511\end{array}$ & $\begin{array}{l}\text { 7150-T77511 } \\
\text { 7055-T79511 (A390) } \\
\text { 7449-T79511 }\end{array}$ & \\
\hline \multirow[b]{2}{*}{ 主翼下面 } & 板 & 2024-T351 & 2324-T39 & 2027-T351 & \\
\hline & 押出材 & 2024-T3511 & $\begin{array}{l}2224-\mathrm{T} 3511 \\
2027-\mathrm{T} 3511\end{array}$ & 2026-T3511 & \\
\hline \multirow{6}{*}{ 胴体 } & 板 & 2024-T3 & 2524-T3 & & \\
\hline & 押出材 & $\begin{array}{l}\text { 2024-T3511 } \\
\text { 7075-T73511 }\end{array}$ & $\begin{array}{l}\text { 2026-T3511 } \\
7150-\mathrm{T} 77511\end{array}$ & 7349-T76 & \\
\hline & フレーム & $\begin{array}{l}\text { 7075-T73 (sheet) } \\
7075-\mathrm{T} 7351\end{array}$ & $\begin{array}{l}\text { 7055-T762 (sheet) } \\
\text { 7050-T7451 }\end{array}$ & 7040-T7451 & 2026-T3511 \\
\hline & シート・トラック & 7075-T73511 & 7150-T77511 & 7349-T76 & \\
\hline & フロア・ビーム & 7075-T7351 & 7050-T7451 & 7150-T7751 & 7055-T7751 \\
\hline & スタンション & 7075-T73511 & 7150-T77511 & 7349-T76 & \\
\hline
\end{tabular}

AA（The Aluminum Association）に登録された合金である。 これらを含めAAに登録されている代表的な航空機用 2000 系，7000系合金の成分を表2 に示す ${ }^{23) 。 ~}$

7000 系合金で特徴的なことは亜鉛が7〜 10\%程度まで添加 された合金が多くなっていることである。日本で戦前発明 され零戦に採用された超々ジュラルミン（ESD）が表2最下 段に示すように亜鉛は6〜9\%であったので，世界はようや く超々ジュラルミンのレベルまできたとも言えよう。もうひ とつは2000系も含めて, 使用する地金が高純度化されてい ることである。これは材料の不純物元素に起因する化合物を 減少させて, 高勒性化や疲労き裂の進展を抑制するためで ある。さらに厚板材や厚肉の鍛造品で焼入れ感受性を鈍感 にするために，添加元素をクロムからジルコニウムに変え ていること, マグネシウム, 銅の添加量を適正化している ことがある。航空機用アルミニウム合金に要求される特性 を表3に示す ${ }^{7)}$ 。材料が航空機に適用されるためには，まず 米国の MMPDS (The Metallic Materials Properties Development and Standardization: 旧MIL-HDBK5）の規格に登録されるこ とが求められる。このMMPDSには航空機用材料の強度等 の設計データが含まれている。Al-Li合金を除く MMPDS09 (April 2014）に登録されている2000系と7000系合金の特 徵と使用形態，調質を表4-1〜4-3に示す ${ }^{24)}$ 。それらの合金 の強度比較を図8に示す ${ }^{13)}$ 。表 5 にMRJのベース合金と今後 適用される候補合金を示す ${ }^{13)}$ 。

\section{2 第三世代Al-Li合金の動向}

$\mathrm{Li}$ は金属元素中最も密度が低く $0.53 \mathrm{Mg} / \mathrm{m}^{3}$ で, リチウムを アルミニウムに 1 mass $\%$ 添加することで剛性は約 $6 \%$ 上昇し, かつ密度は約 3\%低下することから, 航空機用アルミニウム 材料のさらなる軽量化を目的として 1980 年代に研究開発な らびに機体への適用検討が行われた。しかしながら，第二世 代と呼ばれるこの Al-Li 合金は Li 含有量が 2 mass\%を超え密
度は小さくなったものの,（1）強度異方性，（2）低い破壊勒 性,（3）低い耐食性, などいくつか問題があり航空機への 適用は非常に限定的であった。1990年後半から第三世代の Al-Li合金としてこれらの問題点を克服しょうと開発が行わ れており，現在も欧米を中心に開発が行われている ${ }^{25)}$ 。第 一世代から第三世代までの Al-Li合金開発の流れを図9に示 す26)。

表6にAAに登録されている Al-Li合金の成分を示す ${ }^{23)}$ 。 この表に示した2094合金以降が第三世代 Al-Li 合金と呼ば れるもので, 化学組成の特徵としては $\mathrm{Li}$ 含有量が $2 \%$ 以下 となっている。各種 $\mathrm{Al}-\mathrm{Li}$ 合金の強度を図 10 に示す。図 11 にリチウム含有量と合金密度の関係を示す ${ }^{19)}$ 。第二世代の 密度低下は7075 合金と比較して3〜6\%であるので, 比強 度は7075 合金に比べて増加するものもある。この MMPDS09 (April 2014）に登録されている Al-Li合金の特徵と使用形 態, 調質を表 7 に示す ${ }^{24)}$ 。

第二世代と第三世代の $\mathrm{Al}-\mathrm{Li}$ 合金の機械的特性，破壊勒性， 耐食性や製造プロセスを比較すると，第二世代の Al-Li 合金 は（1）低密度,（2）高剛性，（3）高疲労寿命などの良好な 特性を持つ反面，（1）機械的特性の面内異方性が大きい，(2) 板厚（ST）方向の破壊䩒性が低い,（3）平面応力下の破壊 鞎性が低いなどの欠点があった。第三世代の Al-Li合金では これらの久点を改善するため, (a) 強化機構, (b) 鞀性制 御, (c) 再結晶制御, (d) 結晶粒径および集合組織制御, (e) 疲労特性向上および（f）耐食性向上に関して各種第二相粒 子および添加元素の働きについて詳細な研究が行われてい る。Al-Li 合金において最適な機械的特性を得るためには, 可能な限り未再結晶組織として製造するためにクロス圧延や 溶体化処理前に回復焼鈍を実施するなどの加工熱処理法が検 討されている ${ }^{25)}$ 。

一般的に構造設計時には最も低い方向の特性を基準として 

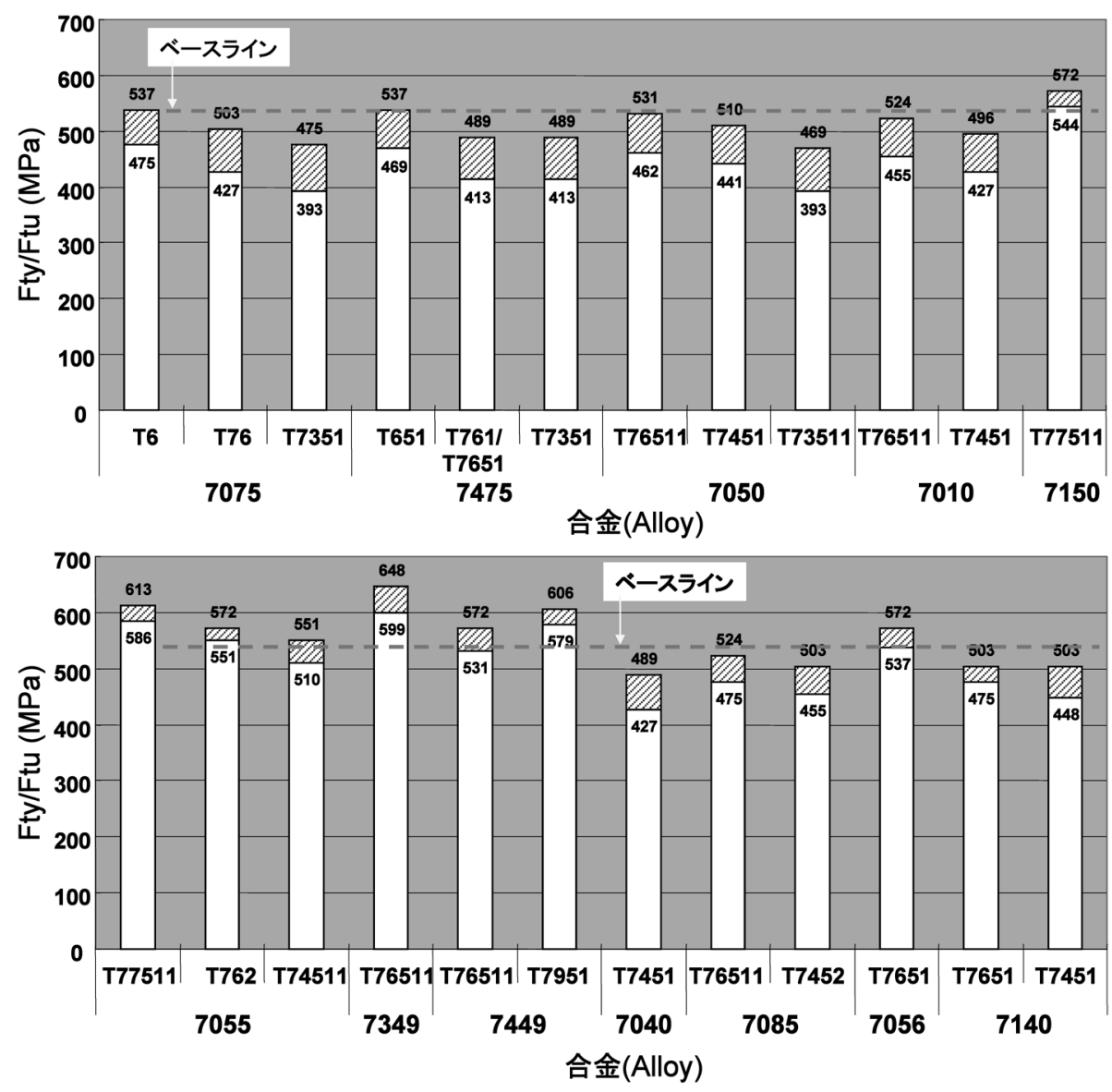

図8 MMPDSに揭載された各種航空機用 7000 系合金の引張強さ (Ftu) と耐力 (Fty $)^{13)}$

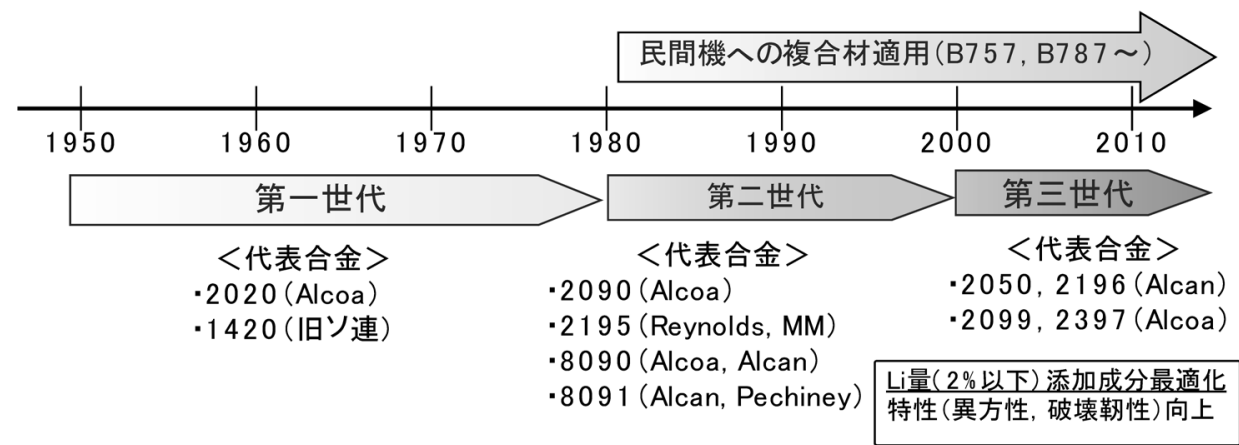

\section{*2020 合金}

米·偵察機RA-5Cに採用 (上下面主翼外板)。

$\rightarrow$ 延性亡破壊靶性が問題亡 なり,すぐに使用中止。

$1420(\mathrm{Al}-5 \mathrm{Mg}-2 \mathrm{Li}-0.1 \mathrm{Zr})$ MIG2 9 の溶接胴体やコック ピットに使用。低強度のため、 拡大せず。
B777，戦闘機等へ適用検討 破壊靬性などに課題がある ため,限定採用

第二世代のAl-Li合金課題 低破壊靬性値

耐剥離腐食が劣る(ED) 強度の異方性が大きい (非再結晶組織) 圧延性 (耳割れなど)

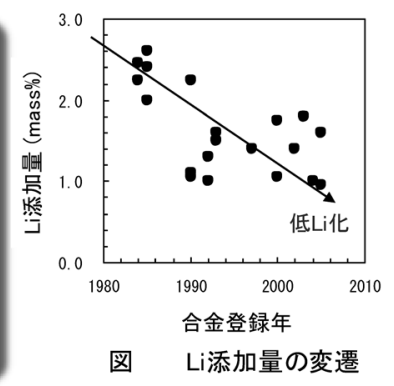

図9 Al-Li合金開発の流れ ${ }^{26)}$

行われるため，機械的特性の異方性は最小にすることが望ま れている。また第二世代 Al-Li合金は面内異方性が大きく, 特に $45^{\circ}$ 方向の強度が低いという問題点があった。これらは 主に集合組織や結晶粒の粒径や形状および析出相によるもの で，第三世代Al-Li合金では面内異方性および板厚方向の異 方性が改善されている ${ }^{25)}$ 。
破壊䩲性の向上には不溶性の第二相粒子の影響が大きく， 結晶粒界近傍のPFZの制御や不溶性の第二相粒子の低減およ び未再結晶組織あるいは再結晶粒の形状制御によって破壊 鞁性の向上が図られている。さらに第三世代 $\mathrm{Al}-\mathrm{Li}$ 合金は耐 応力腐食割机性についても大きく向上しており, 現行材の 2000 系，7000系合金や第二世代 Al-Li合金と比べて SCCが生 
表6 AAに登録されている Al-Li合金の成分 ${ }^{23)}$

\begin{tabular}{|c|c|c|c|c|c|c|c|c|c|c|c|c|}
\hline No. & Date & By & $\mathrm{Si}$ & $\mathrm{Fe}$ & $\mathrm{Cu}$ & $\mathrm{Mn}$ & $\mathrm{Mg}$ & $\mathrm{Zn}$ & $\mathrm{Ag}$ & $\mathrm{Li}$ & $\mathrm{Zr}$ & $\mathrm{Ti}$ \\
\hline 8090 & 1984 & EAA & 0.2 & 0.3 & $1.0-1.6$ & 0.1 & $0.6-1.3$ & 0.25 & - & $2.2-2.7$ & $0.04-0.16$ & 0.1 \\
\hline 2090 & 1984 & USA & 0.1 & 0.12 & $2.4-3.0$ & 0.05 & 0.25 & 0.1 & - & $1.9-2.6$ & $0.08-0.15$ & 0.15 \\
\hline 8091 & 1985 & UK & 0.3 & 0.5 & $1.6-2.2$ & 0.1 & $0.50-1.2$ & 0.25 & - & $2.4-2.8$ & $0.08-0.16$ & 0.1 \\
\hline 2091 & 1985 & FRANCE & 0.2 & 0.3 & $1.8-2.5$ & 0.1 & $1.1-1.9$ & 0.25 & - & $1.7-2.3$ & $0.04-0.16$ & 0.1 \\
\hline 8093 & 1990 & FRANCE & 0.1 & 0.1 & $1.0-1.6$ & 0.1 & $0.9-1.6$ & 0.25 & - & $1.9-2.6$ & $0.04-0.14$ & 0.1 \\
\hline 2094 & 1990 & USA & 0.12 & 0.15 & $4.4-5.2$ & 0.25 & $0.25-0.8$ & 0.25 & $0.25-0.6$ & $0.7-1.4$ & $0.04-0.18$ & 0.1 \\
\hline 2095 & 1990 & USA & 0.12 & 0.15 & $3.9-4.6$ & 0.25 & $0.25-0.8$ & 0.25 & $0.25-0.6$ & $0.7-1.5$ & $0.04-0.18$ & 0.1 \\
\hline 2195 & 1992 & USA & 0.12 & 0.15 & $3.7-4.3$ & 0.25 & $0.25-0.8$ & 0.25 & $0.25-0.6$ & $0.8-1.2$ & $0.08-0.16$ & 0.1 \\
\hline 2097 & 1993 & USA & 0.12 & 0.15 & $2.5-3.1$ & $0.10-0.6$ & 0.35 & 0.35 & - & $1.2-1.8$ & $0.08-0.16$ & 0.15 \\
\hline 2197 & 1993 & USA & 0.1 & 0.1 & $2.5-3.1$ & $0.10-0.50$ & 0.25 & 0.05 & - & $1.3-1.7$ & $0.08-0.15$ & 0.12 \\
\hline 2297 & 1997 & USA & 0.1 & 0.1 & $2.5-3.1$ & $0.10-0.50$ & 0.25 & 0.05 & - & $1.1-1.7$ & $0.08-0.15$ & 0.12 \\
\hline 2397 & 2002 & USA & 0.1 & 0.1 & $2.5-3.1$ & $0.10-0.50$ & 0.25 & $0.05-0.15$ & - & $1.1-1.7$ & $0.08-0.15$ & 0.12 \\
\hline 2196 & 2000 & USA & 0.12 & 0.15 & $2.5-3.3$ & 0.35 & $0.25-0.8$ & 0.35 & $0.25-0.6$ & $1.4-2.1$ & $0.04-0.18$ & 0.1 \\
\hline 2296 & 2010 & France & 0.12 & 0.15 & $2.1-2.8$ & $0.05-0.50$ & $0.20-0.8$ & 0.25 & $0.25-0.6$ & $1.3-1.9$ & $0.04-0.18$ & 0.1 \\
\hline 2098 & 2000 & USA & 0.12 & 0.15 & $3.2-3.8$ & 0.35 & $0.25-0.8$ & 0.35 & $0.25-0.6$ & $0.8-1.3$ & $0.04-0.18$ & 0.1 \\
\hline 2198 & 2005 & USA & 0.08 & 0.1 & $2.9-3.5$ & 0.5 & $0.25-0.8$ & 0.35 & $0.10-0.50$ & $0.8-1.1$ & $0.04-0.18$ & 0.1 \\
\hline 2099 & 2003 & USA & 0.05 & 0.07 & $2.4-3.0$ & $0.10-0.50$ & $0.10-0.50$ & $0.40-1.0$ & - & $1.6-2.0$ & $0.05-0.12$ & 0.1 \\
\hline 2199 & 2005 & USA & 0.05 & 0.07 & $2.3-2.9$ & $0.10-0.50$ & $0.05-0.40$ & $0.20-0.9$ & - & $1.4-1.8$ & $0.05-0.12$ & 0.1 \\
\hline 2050 & 2004 & USA & 0.08 & 0.1 & $3.2-3.9$ & $0.20-0.50$ & $0.20-0.6$ & 0.25 & $0.20-0.7$ & $0.7-1.3$ & $0.06-0.14$ & 0.1 \\
\hline 2055 & 2011 & USA & 0.07 & 0.1 & $3.2-4.2$ & $0.10-0.50$ & $0.20-0.6$ & $0.30-0.7$ & $0.20-0.7$ & $1.0-1.3$ & $0.05-0.15$ & 0.1 \\
\hline 2060 & 2011 & USA & 0.07 & 0.07 & $3.4-4.5$ & $0.10-0.50$ & $0.6-1.1$ & $0.30-0.50$ & $0.05-0.50$ & $0.6-0.9$ & $0.05-0.15$ & 0.1 \\
\hline 2076 & 2012 & France & 0.1 & 0.1 & $2.0-2.7$ & $0.15-0.50$ & $0.20-0.8$ & 0.3 & $0.15-0.40$ & $1.2-1.8$ & $0.05-0.16$ & 0.1 \\
\hline 2065 & 2012 & France & 0.1 & 0.1 & $3.8-4.7$ & $0.15-0.50$ & $0.25-0.8$ & 0.3 & $0.15-0.50$ & $0.8-1.5$ & $0.05-0.15$ & 0.1 \\
\hline
\end{tabular}

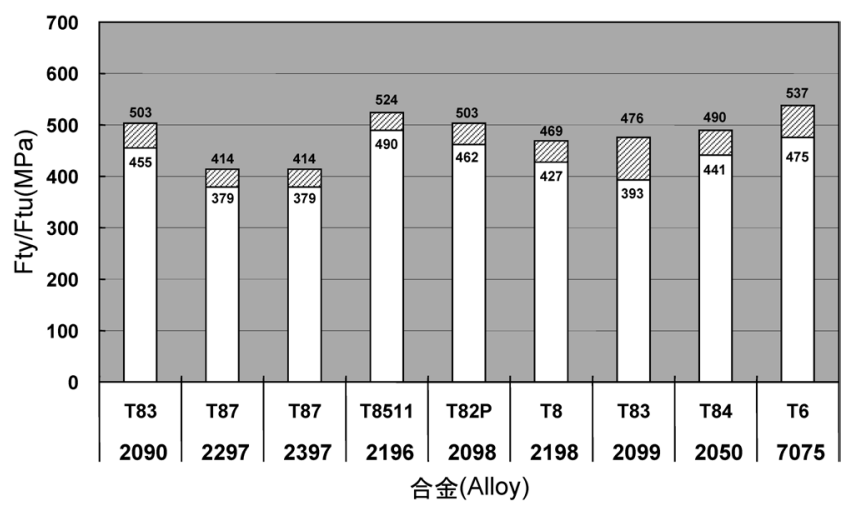

図 10 MMPDSに登録された各種 Al-Li合金の引張強 さ $(\mathrm{Ftu})$ と耐力 $(\text { Fty })^{19)}$

\section{じるしきい応力が高いことが言われている ${ }^{25)}$}

以上のように第三世代 Al-Li合金は合金自体の密度は大き くなっているが，合金によっては比強度は第二世代 Al-Li合 金を超える場合もある。打ち上げ用ロケットのタンクに使用 した $\mathrm{Al}-\mathrm{Li}$ 合金の特性の一例を $\mathrm{Li}$ を含まない従来合金と比較 して表8に示す ${ }^{27)}$

第三世代 Al-Li合金はエアバス社の A380のフロアビーム やボンバルディア社の Global C-Seriesに採用されており, 今 後もエアバス社のA320neo, A330neo, A380neo どに照準を 合わせて欧米を中心に開発が行われている。現在海外アルミ メーカーでは $\mathrm{Al}-\mathrm{Li}$ 合金鋳造設備の増強が行われているとの 情報もあるが， $\mathrm{Al}-\mathrm{Li}$ 合金の大きな課題はコストであり，現

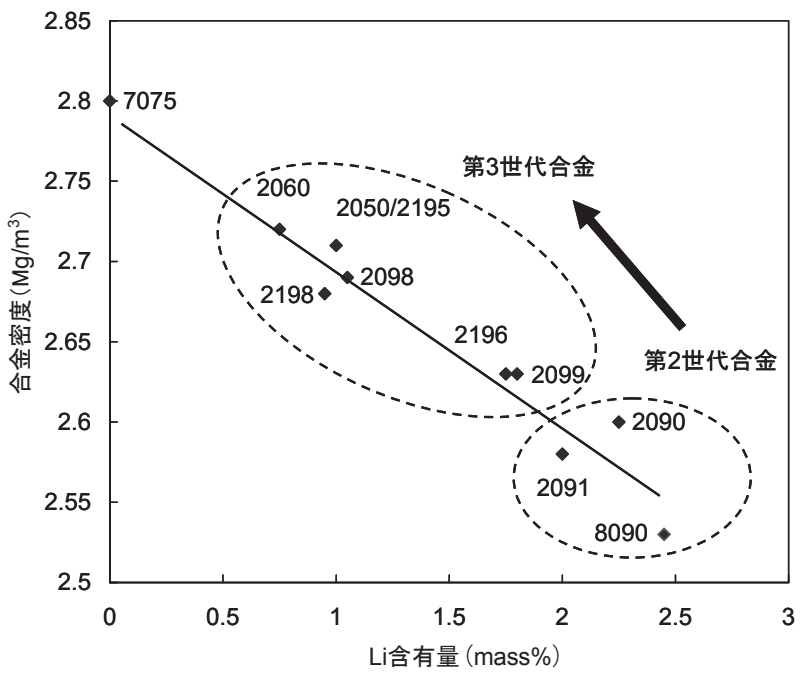

図 11 第三世代の Al-Li 合金の Li含有量と密度の関係 ${ }^{19)}$

行材の 2 4 倍と言われている。またリサイクル性に関して も懸念が残る。航続距離の長い大型機や中型機においては CFRPに対抗するべくAl-Li合金が開発されていると言えよう。

\section{3 戦後初の国産の航空機用 2013 合金の開発}

最近の航空機材開発の流れは, 従来からの超々ジュラルミ ンを超える高強度高勒性材料の開発ともうひとつは航空機製 造のコスト低減化に寄与できる材料, 技術開発がある。後者 における材料開発では, 耐食性で優れている6000系合金が 注目され，米国では6013合金が開発された。2024合金に比 
表 7 MMPDSに登録されている航空機用 $\mathrm{Al}-\mathrm{Li}$ 系合金の特徵, 使用形態, 調質 ${ }^{24)}$

\begin{tabular}{|c|c|c|c|}
\hline 合金 & 特徵 & 形態 & 調質 \\
\hline 2050 & $\begin{array}{l}\text { 本合金は } \mathrm{Al}-\mathrm{Cu}-\mathrm{Li}-\mathrm{Mg}-\mathrm{Zr} \text { 合金で 0.50-5.00 インチ厚板用に設計され，調質としては } 84 \text { が登録されてい } \\
\text { る。本合金は } 2098 \text { 合金の } \mathrm{Mn}, \mathrm{Mg}, \mathrm{Li} \text { 適正化した合金である。高強度, 高䩚性, 高耐食性を有し, 從 } \\
\text { 来 } 2000 \text { 系/7000系航空機材に比べ高剛性, 低密度を示している。 }\end{array}$ & 厚板 & T84 \\
\hline 2090 & $\begin{array}{l}\text { 本合金は } \mathrm{Al}-\mathrm{Cu}-\mathrm{Li} \text { 合金で, 7075-T6 と同等の強度を有し，密度を } 8 \% \text { 低減, 剛性を } 10 \% \text { 向上させた合金 } \\
\text { である。薄板はT83で使用される。2090薄板は7075-T6 と同等の強度を有しながら, 耐剥離腐食性に優 } \\
\text { れている。 }\end{array}$ & 薄板 & T83 \\
\hline 2098 & $\begin{array}{l}\text { 本合金は } \mathrm{Al}-\mathrm{Cu}-\mathrm{Li}-\mathrm{Mg}-\mathrm{Ag} \text { 合金で, 7075-T6と同等の強度を有し，損傷許容や耐疲労き裂進展性は7475- } \\
\mathrm{T} 7351 \text { と同等である。7475合金に比べて3\%の密度低下と5\%の剛性が向上している。薄い厚板では } \mathrm{O} \\
\text { 材，薄板ではT8調質で製造される。溶体化処理，引張矯正，時効処理して熱的に安定な-T82P調質と } \\
\text { する。この最終の熱処理で耐食性に優れた製品になる。 }\end{array}$ & $\begin{array}{l}\text { 厚板, } \\
\text { 薄板 }\end{array}$ & $\begin{array}{l}\text { T82P, } \\
\text { T8 }\end{array}$ \\
\hline 2198 & $\begin{array}{l}\text { 本合金は } \mathrm{Al}-\mathrm{Cu}-\mathrm{Li}-\mathrm{Mg}-\mathrm{Ag} \text { 合金で, } 2098 \text { の派生合金である。2198合金は高純度地金を使用し，成分の } \\
\text { 最適化を図ることで，強度を維持しつつ損傷許容性を高めた航空機部品用に開発された。薄板用で } \mathrm{T} 8 \\
\text { 調質が登録されている。 }\end{array}$ & 薄板 & $\mathrm{T} 8$ \\
\hline 2099 & $\begin{array}{l}\text { 本合金は } \mathrm{Al}-2.7 \mathrm{Cu}-1.8 \mathrm{Li}-0.7 \mathrm{Zn}-0.3 \mathrm{Mg} \text { 合金で, 主に押出棒や形材として利用されている。これらの押出 } \\
\text { 材は高強度, 高剛性, 低密度, 高耐食性が必要な部品に適用される。またこの合金は機械加工性, 良 } \\
\text { 好な仕上げ加工性, 成形性にも優れる。厚板としても利用されている。調質としては } 86, \mathrm{~T} 83, \mathrm{~T} 81 \text { の } 3 \\
\text { 種類が登録されている。 }\end{array}$ & $\begin{array}{l}\text { 厚板, } \\
\text { 押出形材 }\end{array}$ & $\begin{array}{l}\text { T86, } \\
\text { T83, } \\
\text { T81 }\end{array}$ \\
\hline 2195 & $\begin{array}{l}\text { 本合金は } \mathrm{Al}-\mathrm{Cu}-\mathrm{Li}-\mathrm{Mg}-\mathrm{Ag} \text { 合金である。薄板あるいは主に0.500-2.250インチの厚板用に用いられる。 } \\
\mathrm{T} 34 \text { 状態で製造され，ユーザーの成形・時効処理によって最終T82 調質として用いられる。規格として } \\
\text { はT8 T } 8 \text { と } 82 \text { が登録されている。低密度, 高強度, 高損傷許容性, 高耐応力腐食割れ性を必要とする航 } \\
\text { 空機部品向けに開発された。 }\end{array}$ & $\begin{array}{l}\text { 薄板, } \\
\text { 厚板 }\end{array}$ & $\begin{array}{l}\text { T8, } \\
\text { T82 }\end{array}$ \\
\hline 2196 & $\begin{array}{l}\text { 本合金は } \mathrm{Al}-\mathrm{Cu}-\mathrm{Li}-\mathrm{Mg}-\mathrm{Ag} \text { 合金で, 低密度, 高強度, 高剛性で切削時の形状安定性が要求される航空機 } \\
\text { 部品用に開発された。押出用で調質はT8511が登録されている。 }\end{array}$ & 押出 & T8511 \\
\hline 2297 & 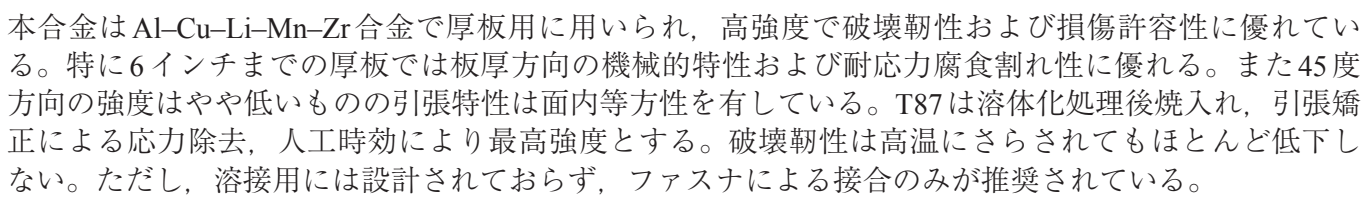 & 厚板 & T87 \\
\hline 2397 & 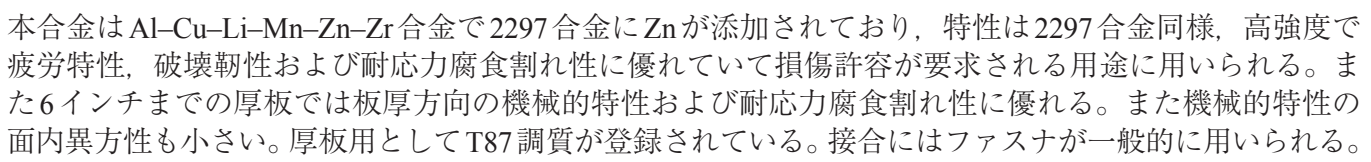 & 厚板 & T87 \\
\hline
\end{tabular}

表 8 各種 Al-Li合金の物理的性質と機械的性質 ${ }^{27)}$

\begin{tabular}{|c|c|c|c|c|c|c|}
\hline 合金·質別 · 製品 & $\begin{array}{c}\text { 密度 } \\
\left(\mathrm{Mg} / \mathrm{m}^{3}\right)\end{array}$ & $\begin{array}{c}\text { 弾性率（引張） } \\
\left(10^{3} \mathrm{GPa}\right)\end{array}$ & $\begin{array}{c}\text { 引張耐力（L) } \\
(\mathrm{MPa})\end{array}$ & $\begin{array}{c}\text { 破壊靶性 }(\mathrm{L}-\mathrm{T}) \\
K_{\mathrm{IC}},{ }^{*} K_{\mathrm{C}} \\
\left(\mathrm{MPa} \mathrm{m}{ }^{1 / 2}\right)\end{array}$ & 比強度 & 比剛性 \\
\hline 2090-T83 Sheet & 2.59 & 79.3 & 517 & $*_{44}$ & 200 & 30.6 \\
\hline 2195-T8R78 Plate & 2.71 & 76.0 & 530 & 37 & 196 & 28.0 \\
\hline 2099-T86 Plate & 2.63 & 77.9 & 483 & 45 & 184 & 29.6 \\
\hline 2055-T8EX Plate & 2.70 & 76.6 & 655 & 28 & 243 & 28.4 \\
\hline 2219-T851 Plate & 2.84 & 73.1 & 352 & 36 & 124 & 25.7 \\
\hline 5456-H116 Plate & 2.66 & 71.0 & 255 & - & 96 & 26.7 \\
\hline 7075-T651 Plate $(* *)$ & 2.81 & 71.0 & 546 & 28 & 194 & 25.3 \\
\hline 7050-T7451 Plate $(* *)$ & 2.83 & 71.0 & 494 & 43 & 175 & 25.1 \\
\hline
\end{tabular}

(**) は吉田英雄：学位論文（1991）より

ベ耐食性が優れるためクラッド材を用いる必要がなく, さら に腐食環境にさらされた後の疲労強度は2024合金と同等で ある。
日本においても, 川崎重工業と住友軽金属（現 UACJ） は日本航空宇宙工業会の委託研究として, 2024 合金-T3 材の 強度に匹敵し，6013 合金より高強度の6000系板材を開発し， 


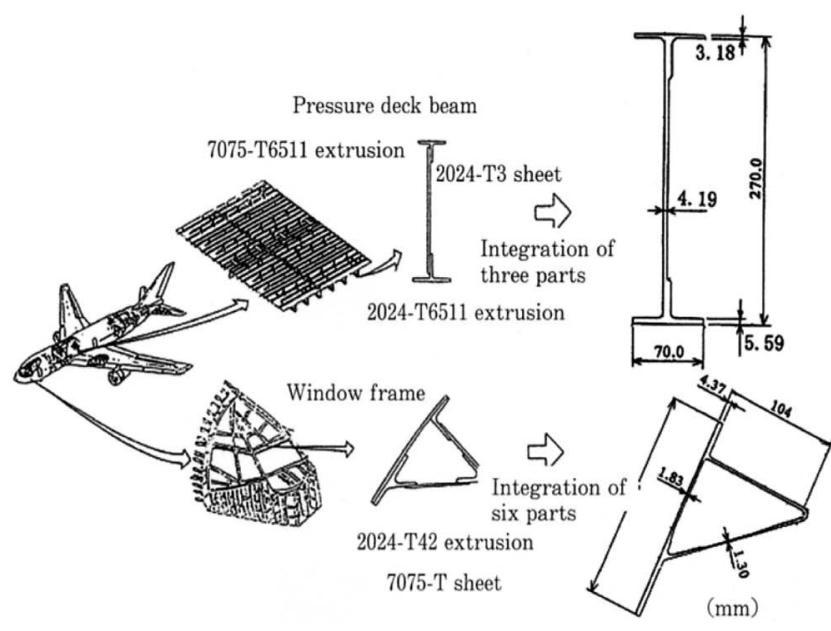

図 12 AA2013 合金押出材を用いて一体化加工した部品 例 ${ }^{30)}$

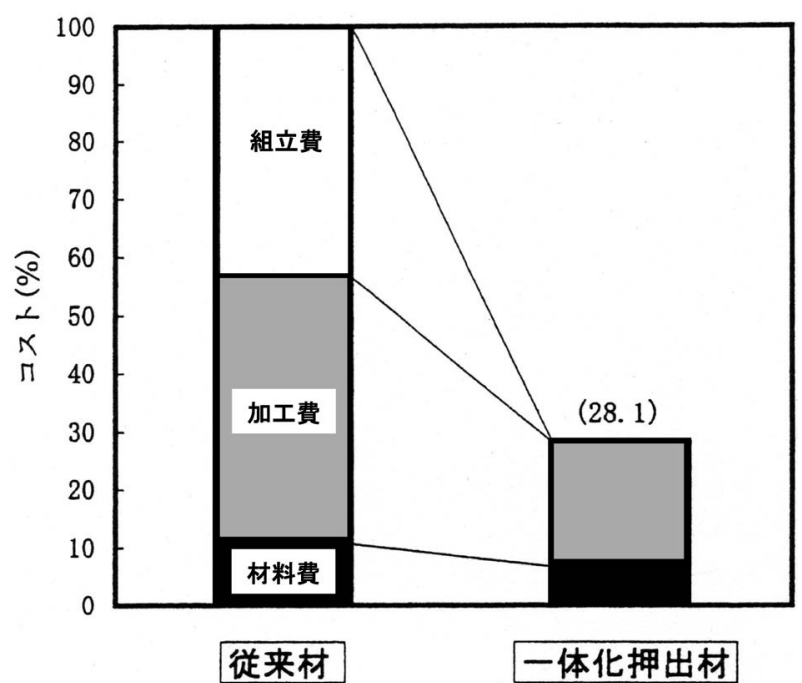

図13従来の製造法とAA2013 合金を用いた一体化押出 による製造法とのコスト比較 ${ }^{34)}$

航空機に適用する検討を行った ${ }^{28)}$ 。この板材を用いると, 従来2024-O材で成形し，焼入れしていた工法が，T4で成形 し成形後人工時効する工程が可能となり, 成形加工後の焼入 れによるひずみ矯正が不要で製造コストが約 30\%低減する。 この合金はまた，図12に示すように，従来の2000系合金で はできなかった中空薄肉ホロー形材が押出可能で, 複雑な形 状の航空機部品の一体化成形ができ，従来のリベット接合が 不要になり重量軽減が図れ，図13に示すように低コストで 製造できることが明らかとなった ${ }^{29)}$ 。

この高強度高成形 6000 系合金は2013合金として，米国 の AAに国際登録され，その押出材は米国の航空機規格 MMPDSを取得している ${ }^{30)}$ ３7)。日本で最初にMMPDSに登 録された国産合金である。この合金は航空機のコスト低減が 可能で軽量化に寄与できるもので, 今後の航空機の設計にぜ ひ織り込んで欲しいと考える。戦後, 住友を見学した堀越二 郎氏は，現場でホロー形材をみて，こんなものがアルミニウ ムでできるならばもっと違った航空機もできただろうとの感 想を述べている ${ }^{38)}$ 。航空機の設計者にアルミニウムの製造 現場を見ていただくのはとても重要なことである。

\section{4. 航空機用材料の今後の課題}

\section{1 航空機用材料の市場, 欧米との比較}

アルミニウム産業における国内の航空機向けアルミニウ ム材の生産量は2012年約 4000 トンで, アルミニウム圧延 品（板, 押出）の年間国内生産量 200 万トンの $0.2 \%$ 程度で ある。国内での航空機生産に使用するアルミニウム材料は 約 36000 トンで約 9 割が輸入材である。日本航空宇宙工業会 「航空機用アルミニウム合金の生産能力の実態及び課題の調 査」(平成 14年 3 月) の資料では2016 2020年民間機（大型 機, リージョナル機) 用アルミニウム素材市場推定では世界 で約 27 万トン/年あるといわれている ${ }^{39)}$ 。

日本の航空機メーカーはアルミニウムの素材を, 米国をは じめとして圧倒的に海外に依存している。この原因は, 大型 設備で大量生産された海外製品が安いということと日本国内 ではその製造工程が複雑で生産性が低く, それよりも午材な どの製品を大量に生産した方が時間当たりの利益が大きいと いったことが挙げられる。そのため日本でしか製造できない ような特殊な航空機材料しか注文がこないことになる。さら に，アルコア社は7055-T7751 といった特殊な熱処理された 合金を特許化して，それをボーイング社に認定させ他社が参 入できないようにしていることも挙げられる。かくして日本 製品は航空機材料市場にほとんど入れていないのが現状であ る。このため高強度材料の開発や製造技術もまた海外勢に遅 れを取っている。

海外勢に対抗するには航空機材の生産性が課題で，生産性 を上げ低コスト化を図るか, 短納期で寸法精度が高く残留応 力の少ない高品質の素材を生産し, 機体メーカーや部品メー カーでの加工コスト低減に寄与できる製品を製造していくか にかかっている。いずれにしても機体メーカー, 部品メー カーの協力が必要である。需要のないところでは技術も研究 も廃れていくのは当然である。戦前の国策として航空機のた めにアルミニウム産業を育成してきた状況とは大きく異なっ ている。

\section{2 航空機材料開発の課題, 軽金属学会東海支部航空機 材料部会の活動に即して ${ }^{40)}$}

軽金属学会東海支部は, 2010 年, こうした最近の東海地 区の航空機産業の状況を鑑みて，アルミニウム材料を継続的 に用いていただくために，産として素材メーカー，機体メー カー, 部品加工メーカー, 表面処理メーカー, 官として中部 経済産業局, 愛知県労働産業部, 産業技術総合研究所, 中部 航空宇宙技術センター, 学として名古屋大学, 大同大学など を入れた産官学の航空機材料部会（部会長 名古屋大学 金武 直幸教授）を発足させた。ここで航空機用アルミニウム材 料の現状把握と課題の抽出を行い, 素材製造 WG, 切削加工 WG，リサイクルWG，表面処理WGの4つのワーキンググ ループに分けて，ワーキンググループごとに将来の技術課題 を検討した。素材WGからは, 形材の寸法精度向上技術, ブ リスター発生抑制技術，高強度高剛性合金の開発，大型素材 の国産化, 切削加工WG 削後の変形予測技術，加工発熱の少ない高速加工技術などの 開発, リサイクルWGからは can to canのようなリサイクル システム構築, 二輪車部品への再利用技術の開発, 表面処理 WGからは, 素材, 表面処理, 使用環境が耐食性に及ぼす影 
響の解明，環境適合でかつ自己修復機能を持った表面処理技 術の開発が将来の技術課題として提案された。この活動をさ らに発展させ, 素材メーカー, 機体メーカー, 部品メーカー が一緒になって課題を解決できる仕組みができれば，さらに 素晴らしい材料開発ができるものと考える。

\section{5. おわりに}

東海支部航空機材料部会では将来技術課題をまとめたが, これを実行に移していくには個別の会社ごとに取り組むのは 非常に難しいのが現状で，ぜひ，国家プロジェクトとして総 合的に取り組んでいく必要がある。航空機産業は自動車産業 と並んで東海地区の基幹産業で発展の原動力となっている。 航空機産業を支えていくには各種の基盤技術の確立が必要で あるが，アルミニウムに関してはこのような基盤技術を促進 させるセンターがないので，国はこれを設立させ基盤技術を 牽引していくことが切望される。

高強度合金開発では, 超々ジュラルミンの発見から 80 年 近い年月が経っていて，この間の製造技術も大きく発展して いるが，合金成分で見る限りクロムがジルコニウムに置き換 わっただけであまり進んでいないとも言える。いま，この 超々ジュラルミンを超える材料が求められている。しかし既 存のプロセスだけでは限界があることも確かである。強度を 上げようとすると，延性や勒性が低下してしまうことであ る。これらの原因の一つに，鋳造時に晶出物が生成し，これ が粗大化し結晶粒界に残存することがある。晶出物の生成を 抑制あるいは微細化できる鋳造技術が必要である。また生成 しても，その後の加工熱処理で晶出物を粒内に取り达むこと ができれば粒界割れを抑制でき，延性，勒性を向上させるこ とができるであろう。日本の英知を結集して超々ジュラルミ ンを超える材料を開発して，世界に通用する航空機材料とし て貢献できることが必要である。また最近欧米で復活してき た Al-Li合金については，機体メーカーとあらためてその必 要性を議論したうえで，アリシウムの経験を踏まえ，合金成 分，溶解鋳造について国家プロジェクトとして検討すべき課 題であろう。こうした課題を実行していくためにもナショナ ルセンターが必要である。

\section{参 考 文 献}

1) 吉田英雄：軽金属，65（2015），432-440.

2) A. S. Warren: Proceedings of the 9th International Conference on Aluminium Alloys, Edited by J. F. Nie, A. J. Morton and B. C. Muddle, IMEA, (2004), 24-31.

3) M. V. Hyatt and S. E. Axter: Science and Engineering of Light Metals (RASELM'91), Edited by K. Hirano, H. Oikawa and K. Ikeda, The Japan Institute of Light Metals, (1991)，273-280. アルミニウムの製 品と製造技術，軽金属学会，（2001），273.

4) ボーイング $787:$ https://ja.wikipedia.org/wiki/\%E3\%83\%9C\%E3\% 83\%BC\% $\% 3 \% 82 \% \mathrm{~A} 4 \% \mathrm{E} 3 \% 83 \% \mathrm{~B} 3 \% \mathrm{E} 3 \% 82 \% \mathrm{~B} 0787$

5) 青木謙知: 図解 ボーイング 787 vs. エアバスA380, BLUE BACKS, 講談社, (2011).

6) ANA SKY WEB: http://ana.vacau.com/

7) R. J. H. Wanhill: ALUMINUM-LITHIUM ALLOYS, Processing, Properties, and Applications, Edited by N. E. Prasad, A. A. Gokhale and R. J. H. Wanhill, Butterworth-Heinemann, Elsevier, (2014).

8) M. Kunüwer: (Plenary talk) Aerospace Aluminium 2014-111Years of Success, Aluminium Alloys 2014-ICAA14, Trondheim, Norway, (2014).

9) エアバス A350XWB : https://ja.wikipedia.org/wiki/\%E3\%82\%A8\%
E3\%82\%A2\%E3\%83\%90\%E3\%82\%B9A350_XWB

10) 阿施光南：AIRLINE 9（月刊エアライン）, イカロス出版, No. 423，9月号 (2014)，22-27.

11) 阿施光南：A350XWB \& AIRBUS Family, イカロス出版， (2016) $58-83$.

12) MRJ: https://ja.wikipedia.org/wiki/MRJ, http://www.mrj-japan.com/j/

13）八代充造：国産旅客機MRJ 事業への挑戦と適用軽量化材料一 Flying into the future一, 平成 22 年度軽金属学会東海支部 第一 回講演会, (2010).

14) 藤江 壮：MRJの開発状況, http://www.jasst.jp/archives/jasst11n/ $\mathrm{pdf} / \mathrm{S} 1 . \mathrm{pdf}$

15) 平成 26 年度民間輸送機関連デー夕集（YGR-0185），一般財団法 人日本航空機開発協会, 平成 27 年 3 月

16）杉山勝彦：日本のものづくりはMRJでよみがえる!, SB 新書, SBクリエイティブ, $(2015), 72$.

17) 杉本 要：翔べ, MRJ世界の航空機市場に挑む「日の丸ジェッ 卜」, 日刊工業新聞社, (2015).

18) 前間孝則：AIRLINE 9 (月刊エアライン), イカロス出版, No. 423，9月号 (2014)，46-49, AIRLINE 12（月刊エアライン）, イカロス出版，No. 426，12月号（2014），54-67.

19）中沢隆吉, 伊原木幹成：JFA，45 (2014)，17-27.

20）青木謙知：ジェット旅客機を作る技術, サイエンス・アイ新 書, SBクリエイティブ, (2013), 212.

21) 阿施光南：AIRLINE 7 (月刊エアライン), イカロス出版, No. 433，7月号 (2015)，62-69.

22) 野久 徹: 大型機開発のトピックス, 平成 23 年度軽金属学会 東海支部 第一回講演会，(2011）.

23) International Alloy Designations and Chemical Composition Limits for Wrought Aluminum and Wrought Aluminum Alloys: The Aluminum Association, (2015).

24) MMPDS-09 (Metallic Materials Properties Development and Standardization) Chapter 3 Aluminum Alloys (2014), Federal Aviation Administration.

25) R. J. Rioja and J. Liu: Metall. Mater. Trans., A Phys. Metall. Mater. Sci., 43A (2012), 3325-3337.

26）吉田英雄：住友軽金属技報，54（2013），250-263

27) R. J. Rioja, D. K. Denzer, D. Mooy and G. Venema: $13^{\text {th }}$ International Conference on Aluminum Alloys (ICAA13), Edited by H. Weiland, A. D. Rollet and W. A. Cassada, TMS, (2012), 593-598.

28) 日本航空宇宙工業会 : 航空機部品 ·素材産業振興に関する調 査研究, 高強度高成形 6000 系新合金の研究, 住友軽金属工業, 川崎重工業, 成果報告書, No. 806（1994）, No. 904（1995）.

29) 日本航空宇宙工業会: 航空機部品・素材産業振興に関する調 査研究, 新 6000 系合金の航空機用鍛造/押出材の開発, 住友 軽金属工業, 川崎重工業, 成果報告書, No. 1004 (1996), No. 1102 (1997).

30）佐野秀男，松田眞一，吉田英雄：住友軽金属技報，45（2004） 168.

31）佐野秀男，加藤勝也：住友軽金属技報，46（2005）, 126

32）加藤勝也，佐野秀男：住友軽金属技報，47（2006）, 105 .

33）佐野秀男, 加藤勝也：住友軽金属技報, 51（2010）, 166 ,

34) 日本航空宇宙工業会：環境調和型航空機技術に関する調查研 究 (CD 版), 複雑形状の押出可能な高強度合金2013の一次構 造体への適用研究, 住友軽金属工業, 川崎重工業, 成果報告書, No. 1615 (2005), No. 1705 (2006).

35) 日本航空宇宙工業会：環境調和型航空機技術に関する調査研 究 (CD 版), 高成形合金2013板材の開発及び低コス卜構造へ の適用研究, 住友軽金属工業, 川崎重工業, 成果報告書, No. 1914 (2008), No. 2006 (2009).

36）岩村信吾，小関好和，吉田英雄：住友軽金属技報，51（2010）, 32.

37）小関好和，岩村信吾，上向賢一，山田悦子：住友軽金属技報, $51(2010), 61$.

38）深井誠吉：軽金属, 29 (1988)， 87.

39) 日本航空宇宙工業会: 平成 13 年度航空機用アルミニウム合金 の生産能力の実態及び課題調査, (2002).

40) 金武直幸：軽金属学会東海支部「航空機材料部会」について, 平成 24 年度軽金属学会東海支部 第一回講演会, (2012). 